Portland State University

PDXScholar

8-1-1968

\title{
Investigation of attitudinal and behavioral changes of selected sixth grade students who attend an outdoor school
}

Robert R. Sesar

Portland State University

Follow this and additional works at: https://pdxscholar.library.pdx.edu/open_access_etds Let us know how access to this document benefits you.

\section{Recommended Citation}

Sesar, Robert R., "Investigation of attitudinal and behavioral changes of selected sixth grade students who attend an outdoor school" (1968). Dissertations and Theses. Paper 533.

https://doi.org/10.15760/etd.533

This Thesis is brought to you for free and open access. It has been accepted for inclusion in Dissertations and Theses by an authorized administrator of PDXScholar. Please contact us if we can make this document more accessible: pdxscholar@pdx.edu. 
AN ABSTRACT OF THE THESIS OF

Robert R. Sesar for the Mater of Sclence in Eoucation. Date thesis is presented August 13, 1968 Title Investigation of Attitudinal and Behavioral Changes of Selected S1xth Grade Students Who Attend an Outdoor School. Abstract approved Michael Hasca, Chairman

The out-of-doons is being utilized increasingly by school personnel for developing prograns to extend the classroom to include the natural environment. It 1 s hoped that a elimate for leaming, enriched with direct laboratory experiences, wil establish a situation where all students benefit. This study is concemed with the investigation of students" attitudes and self-concepts following such an outdoor school experlence.

The students selected for this study attended a sixth grade class from one of the following Oregon schools: Holy Redeemer and George, of Portland; Eastham, located in Oregon Clty, and Ralnier located In the town of Ralnier. The test group spent six days at an outdoor school, altuated in Colton, Oregon. Data was secured from one-hundred and thirty- 
one lxth grade boys and girls from lower to high socloeconomic backgrounds.

The Instruments used to measure and evaluate the peaponse of the group were: (1) An Attltude Scale, contalning sixteen 1 tems, that would demonstrate students' values toward the natural environment, (2) A Concept Scale I, with fifteen 1 tems, that showed responses to what the students thought of hinself. (3) A Concept Scale II, that recorded the students " responses to how they thought others vlewed them. This scale contained lfteen items. (4) A diary was constructed to record the unsolleited comments from the students that attended Holy Redeemer School.

The destgn of the study included testing all the students two weeks before the outdoor experience and flve weeks after by means of the Attitude Scale and the two Concept scales. An Item analysis of the students' diarles was made to record any values that may have been mentioned. A statistical level of rellability was calculated on each of the cohool groups after the posttest.

From the reaults of thla investigation, the following conclustons seemed justifled: The expertence of the out.door school provides opportunitles that affect the attitudes of atudents toward the natural environment in a positive way. The outdoor school increases relationships that are 
3

conduclve to the attainment of favorable self-concepts in the participants. The experience of the outdoor school. had a postltve, measurable efect, on the students as a group, after a prolonged perlod of time. 
PORTLAND STATE COLLEGE

\author{
INVESTIGATION OF ATTITUDINAL AND BEHAVIORAL \\ CHANGES OF SELECTED SIXIH GRADE STUDENTS \\ WHO ATTEND AN OUTDOOR SCHOOI
}

by

ROBERT R. SESAR

\begin{abstract}
A Thesis
Submitted

in partial fulfiliment of the requirements for the degree of MASTER OF SCIENCE IN EDUCATION
\end{abstract}

1968 
TO THE OFFICE OF GRADUATE STUDIES:

The Nembers of the Committee Approve

The Thesis of Robert R. Sesar,

Presented

Wifchael Flasca, Chalman

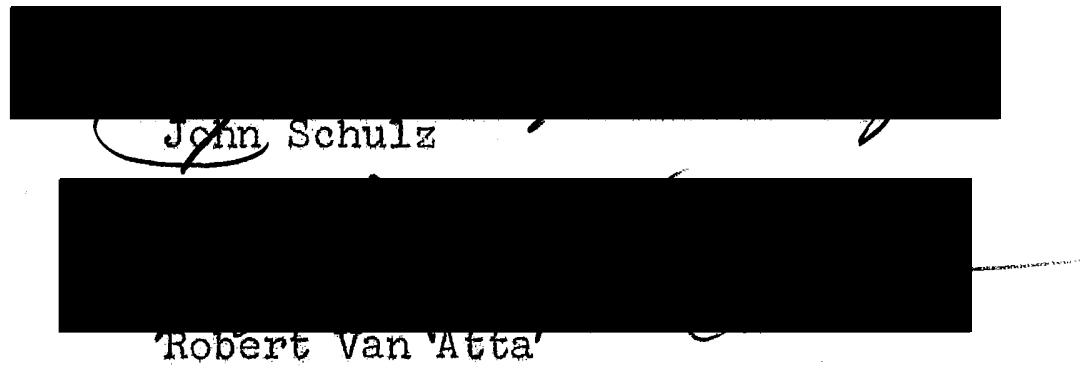

APPROVED:

Frederlck J. Cox, Đan of Graduate Studles

Curg 15, 1968 


\section{ACKNOWLEDGEMENT}

To Dr. Nichael Flasca, chalrman of the thesis committee, Dr. John A. Schulz and Mr. Robert 0 . Van Atta, commltee members, the writer wishes to express genuine gratitude for the support and guidance amply provided at successive stages of development of the investigation.

The writer wishes to express sincere appreciation to Dr. Alma I. BIngham and Dr. Dorris May Lee for their appraisals and helpful suggestions.

To the many teachers that participated in this study and the staff at the Regional Outdoor School thanks are extended. The gratitude of the writer is generous in respect to the assistance provided by Richard Togni regarding the statistics of the study.

Heartfelt thanks are expressed, to my daughter, Pamela Gall, for her timely comments and assistance in developing the concept scales.

$$
\text { R.R.S. }
$$


I INTRODUCTION 1

Statement of the problem I

Historical overview of outdoor schools in Oregon

The nature of outdoor education 4

Definition of terms 6

Importance of the study 7

Scope and limitations of the study 8

Assumptions 9

II THE SAMPLE 10

III RELATED INVESTIGATIONS 14

Conflicting views 24

Related readings 28

IV DESIGN OF THE STUDY 37

Development of the Instruments 37

$V$ ANALYSIS OF THE DATA 43

Attitude scale toward the
natural environment

Concept scales I and II 45

The Diary 79

VI SUMMARY, CONCLUSIONS, AND
RECOMMENDAYIONS

Summary of findings 82

Conclusions 83

Recommendations 84 
TABLE OF CONTENTS, Continued

Page

CHAPTER

BIBLIOGRAPHY

86

APPENDICES

89

Appendix A. Injtial Student Survey Sheet

89

B InItial Student Word

IIst

90

C InItial student Ilst

92

D Concept Scale I

93

E Concept Scale II

95

F Attitude Seale

97 
1 Dally Schedule and Bugle Cal1s 38

2 Weekly Schedule 39

3 Pretest and Post-tost Responses of S1xth Grade Students to Att1tuder Toward the Natural Env1ronment 48

4 Pretest and Post-test Responses of Sixth Grads Students to Concepts of What They Think of Themse1 Concept Scale I

5 Pretest and Post test Responses of S1xth Grade Students to Concepts of What They Thlnk Otherg Think of Them-Concept Scale II

6 Ind1v1dual. Analy 1 s-Attitude Scale Holy Redeemer

7 Ind1v1dual Ana 1yo1s-Concept Scale I Holy Redeemer

8 Individual Analysis-Concept Scale II Holy Redeemen

9 Individual Analyoiem Att tude Soalo George School

10 Ind1vidual Analys1s-Concept Seale I Goorge School

11 Ind1v1dual Analye1. Concept Soale II George School.

12 Ind1v1dual Analys 1 at $t$ t 1 tude Seale Rainter School.

13 Individual Analysis.-Concept Scale I RaInier School

14 Individual Analys1-Concept Scale II RaInler School 
LIST OF TABLES, Continued

Page

TABI

25 Individual Analysie-Attitude Scale Eas tham School

16 Individual Analys 1 -Concept Scale I Eas tham Schoo1

17 Individual Analysis-Concept Scale II Eostham School

18 t Scores of the Attitude Scale and the two Concept Scales

19 Frequency Digtribution of Values Mentioned by Students one Week Before the Outdoor Sohool

Experience, During the Week of School, and One Week After the School 
CHAPTER I

INTRODUCTION

THE PROBLEM

Statement of the problem

This study seeks to Investigate the effect of attendance at the Reglonal Outdoor School upon sixth grade students' changes in self-concepts and the $1 r$ attitude toward the natural environment.

More speciflcally, the following hypotheses are to be tested:

1. Students experiences at the outdoor school will not signiflcantly change their attitude toward the natura1 environment.

2. The experiences attributed to the outdoor school will not significantly change the student's view of himself.

3. The designed instruments will not be effective In assessing student change.

Background for the study

Most personality theorists believe in a concept of self and they tend to support the notion that the self arlses out of social interaction. According to Sullivan (9) a child's earliest appraisal of himself is made up of "reflected appraisals," that is, what others think 
and feel about him. The self-concepts of children have been the subject of empixical meagurement, but these investigations have mostiy been confined to the formal classroom setting.

Many educators are cognizant of the educational Implications offered by outdoor schools, and as a result a large number of such schools have been established throughout Oregon during the past ten years. On the basis of subjective evidence public outdoor schools have been judged to be educationaliy sound, but systematic attempts to evaluate the results of outdoor expertences on the behavior of children have been limited. Historical overviow of public outdoor schools in Oregon

The Outdoor Program in Oregon started in the Spring of 1957. Under the direction of Dr. Irene Hollenbeck, of Southem Oregon College of Education, Ashland, Oregon, the first project was undertaken. A combined fifth and sixth grade class and their teacher from the Westside Elementary School of Medford, Oregon spent a week at Dead Indian Soda Springs Camp, located east of Eagle Point on Iittle Butte Creek.

To further introduce the outdoor school program to administrators, teachers, and parents, and the genera1 public of Oregon, Dr. Margaret Mililken of Oregon State University, Corva11is, Oregon, promoted a series of pllot 
projects in several school districts. In the spring of 1958, the first pllot project started with one sixth grade group from Crook County. They spent rive days at Camp Tamarack, a private camp located near Suttle Lake, in the Oregon Cascade Mountains.

Since that time other projects have been conducted by public schools in other parts of the state, e.g., Parkrose, Clackamas, Tillamook, Hebo, MoMinnville, Salem, West Linn, Coos Bay, Springfield, Mapleton, Beaverton, Prinevilie, Clackamas, Canby, Milwaukle, and Bend (34).

The Regional Outdoor School is the first largescale application of the outdoors a a classroom. This was made posstble through the Elementary and Secondary Act of 1965. The application for the Federal Funds under the act was made by the P.A.R.E.T. (Portland Area Resource Eduoation Tour) Commtttee, a group of state and federa1 resource agency people, Industry representatives, and science educators from Washington, Multnomah, Columbia, and Clackamas Counties.

In the Spring of 1966, five hundred sixth graders from these counties took part in a plilot outdoor school program at Camp Colton, in Colton, Oregon.

In the Fall of 1967, an additional outdoor school was developed on the Sandy River, near Cloverdale, Oregon. During this time there were approximately 1,560 sixth grade students attending the two outdoor schools. 
It was the intent of the P.A.R.E.T. Committee that after the Federal fluancing expired, in the Spring of 1968, the cost of the outdoor program be assimilated into the local school budgets. It was also the Intent of the committee that the outdoor program become part of the regular sixth grade curriculum in the public and parochial schools and annually reach all the 16,000 available sixth grade students in the four county area (29). The nature of outdoor education and the outdoor school

Outdoor education begins when teachers move their students outside the walls of their school to teach those areas of the curploulum which could be taught more effectIvely in a natural outdoor setting $(33, p .43)$. Just as other teaching alds have been used to make instruction more meaningful and realistic, so direct experience that Involves enjoying, observing, and interpreting natural phenomena can be avaliable. These expertences include fleld trips, outdoor classrooms, excursions, nature walks, and native materials brought back into the classroom. However, in order to distinguish between outdoor experiences which take place within the time limit of a single day and those that take place over several days and where the student is away from home, the term outdoor school has been applied to the resident expertence (2, p. 10). 
The twenty-four-hour-a-day experience provides each student with the opportunlty to appreciate those Intangibles that grow out of close association with his peer group. The resident experience also enables the student to study the interrelationships of man as part of the heavens, the soll, the water, the plants, and the other animals. In other words, the outdoor school establishes a laboratory which enables all students to see, feel, hear, and smell the reality about them. This environment will not conserve and maintain Itself unless people are concerned and become conservation minded first. It then seems imperative that we teach our young citizens ideas and ideals that have established themselves to be worthy. Situations and opportunities must be provided that actively involve students in decision making which will nurture responsibility, pride and selfevaluation $(15, p, 13)$.

This educational medium cannot be conceived as an isolated experience. Preparation for an outdoor school implies many hours of curriculum planning prior to the outdoor experience. Observations and learnings gained in the fleld are subsequently broadened and deepened upon retuming. When the outdoor educational experience is integrated into ongoing classroom programs, a potent educational tool is avaliable to be used in many content areas of the curriculum. Intercultural relations and the human understandings, which are the essence of real 
democracy, will inevitably be establtshed when boys and girls have the opportunities to be involved in outdoor expertiences $(5, p, 15)$. Defintition of terms

Appra1sal. To estimate a value or make a valid judgment. Attitudinal outcome. The issues, results, or consequences of changes in values, aversions, or attitudes. The widely accepted definition of an attitude as a predisposition to react favorably or unfavorably toward something, under certain conditions is used $(20$, p. 25).

Classmates. The members of an Identified homeroom class. Natural environment. Natural, in accordance with or determined by nature, everything that is. The word environment is used casually to mean surround-Ings. Everything outside an organism is its environment (4, p. 32). Qutdoor schoo1. An educational enterprise located In an out-of-doors environment, which provides children with the opportunity to (a) live in a group situation (b) obtain insight into the basic processes of $11 f e$, and (c) recelve guldance (3, p. I). 
Self-concept. Those perceptions, beliefs, feelings, and attitudes which the individual views as part or characteristic of himself. Self-esteem, Possesston of a favorable opinion of the self, a favorable self-concept (7, p. 10). IMPORTANCE OF THIS STUDY

This study is important to the degree that it accurately measures speoffic attitudinal outcomes clatined for the outdoor school and analyzes certain valid outcomes in students' self-concepts. Although outdoor schools have gained wide acceptanoe in their relatively short existence in oregon, there are many who would question the educational value of this expertence.

It seems reasonable to expect that the future of the outdoor school probably rests on demonstrable evidence, rather than on theoretical claims. Hence, there is a real need to know what is being accomplished In accurate terms. This study will be important, primarily, to the extent that it provides accurate information of educational outcomes. In the past most evaluation instruments and methods have been ineffective, of nonexistent. Secondarily, this study is important because It will orttically apply speciflo scales, methods, and procedures for the evaluation of the Reglonal Outdoor 
School program now in operation. SCOPE AND IIMITATIONS OF THIS STUDY

The Ilmttations of this study were defined by the behavioral characteristics to be measured, and the population to be examined. In conjunction with the population to be studied, certain practlcal factors were taken Into consideration. Of greatest importance was quantity. In this study, it seemed desirable to do an intenslve investigation with a large population rather than a study using a smal1 control group. Furthermore, It was believed that an experimental school situation could be produced which would be fairly typical of outdoor schools in oregon. It was possible to accomplish this through the cooperation of the following schools: Rainier Elementary School, Rainier, Oregon; Eastham Elementary School, Oregon CIty, Oregon; Holy Redeemer and George Schools, in Portland, Oregon.

In the development of the Investigation the foregoing factors influenced the decision to omit a highly structured control group approach. The approach used would enable the researcher to explore latent attitudes and self-concepts more exclusively. Therefore, the approach followed was one of descriptive survey. The spectific delimitations of this study were the following: 
1. The study was confined to four sixth grade classes.

2. The experimental study was Iimited in time, commencing on Apri1 8, 1968 and terninating on June 4,1968 ,

3. The students were asked to put their names on the three measuring instruments.

4. The results of the study was governed by the sincertty and exactness of the respondents' reactions to the various measuring instruments. ASSUMPTIONS

The following assumptions pertain to this investigation:

1. The outdoor school experiences of six days duration effect behavioral changes in individual students.

2. The kinds and extent of selected self-concepts and behavioral change can be described, measured, and analyzed through the use of measuring instruments used.

3. Pre-outdoor and post-outdoor experiences are a part of the total outdoor experience. 
The selection of the schools and the classes who participate in the Regional Outdoor program is determined by the school administration (29).

Holy Redeemer School, with a population of 607 , is located in North Portland. The school is in the "Model School" area of the Albina district. The public schools in this area are being partially subsidized by Federal Government funds under Title I; Elementary, Secondary Education Act. Holy Redeemer School recelves a small portion of these same funds.

The majority of the students' parents are "blue collar" workers with relatively few "white collar" workers. Most are skilled laborers. There are also a few teachers, one doctor and one attomey represented in the parent group. The average educational status of the adults inside the Parish boundary is at the high school level.

Holy Redeemer School consists of grades one through eight. The sixth grade class that particlpated in this study is heterogeneously grouped and represents a cross section typical of the school and the community (19). Rainier Elementary School is located in the town of Rainier, Oregon, population in 1968 was 1202. A modern sawmil1 employs about 170 of the town' men. Many of 
Rainier's residents cross the Columbia River and work in the industrial plants and sawmills looated in Longview, Washington. There are numerous farms near here specializing in truck-farming. Farm forestry, dalrying, and beef cattle raising also contribute to the town's economy. RaInier grade school is composed of approximately 600 children, grades one through eight. It is the only elementary school located in this community. The participants in this study are from a sixth grade class. The students in this class are heterogeneously grouped and represent a cross section of the school and community.

Eastham elementary school, is located in Oregon City, Oregon. It is one of the larger schools in the Oregon City School district. The district has ten elementary schools, two junior high schools, and one sentor high school. There are twelve teachers for grades one through six with two classes for each grade level at. Eastham. There is one kindergarten teacher, one instructional media teacher, and two teachers for the special education department. The total enroliment is 415 students, grades kindergarten through the sixth. The school is located in a well established neighborhood and has a student body that is stable, that is, few transfers occur during the school year. The school is located near the downtown area and many students' 
parents are professional people. Others work in the downtown stores or one of the large paper mills located in or near this community. The economic level of the families in this area is average. There are a few families who do recelve Aid to Dependent Children. The sixth grade class that participated in this study is heterogeneous Iy grouped. The class represents a cross section of the school and no attempt was made to select any of the participants.

George elementary school is located in the St. Johns area of Portland, Oregon. It is a public school and consists of three kindergarten classes and grades one through elght. The total enrollment of George school is 631 students, After completing the eighth grade students attend Roosevelt high school.

George school was a particlpant in the "Model School" program but because of its boarder line economic status was dropped when the program was curtailed. The economic level of this school district is below average. Most of the students' parents are skilled laborers -- union people. There are very few professtonal people living in this district.

The students participating in this study are from one of the two sixth grade classes at George school. Although this sixth grade class is heterogeneously grouped approximately one-half of the students are performing 
below grade level, academically. The chlldren in this study are youngsters from low average to moderately we11-to do socio-economic communities. A1I students thending the secono week of the outdoon chool watel pated in the study. 


\section{CHAPTER III}

RELATED INVESTIGATIONS

In the earlier history of school camping and outdoor education, research was somewhat limited with a few studies beginning to appear by the middle of the nineteen fortles.

A school camp was conducted with Iife Camps, Incorporated in 1945. During the regular school year one fifth grade clags and one seventh grade class spent three weeks at outdoor camps. Sixty-two pupils of both sexes were accompanied by their teachers. These students lived in eight small units of seven or eight students. Each unit did its own cooking and developed its own daily program.

Tests in nature study, sclence, vocabulary, arithmetic, and an interest inventory were constructed and administered. Students were also studied by means of observations, questionnalres, and interviews, Parents, teachers, and supervisors were polled for their opinions. AIl testing and evaluation was done prior to camp and immediately after returning.

Groups tests consisted of an experimental group and a control group. The control group closely approximated the experimental group in intelilgence quotient, age, and academic achievement. Students were matched on the basis of age, sex, intelligence quotient, and reading ability (21). 
The result from the data gathered is as follows:

1. Gains from inftial to final testing favored the experimental group in six of the ten comparisons. Two of the gains, both favoring the experimental group, were statistically significant. They were: interest inventory for the seventh grade students and vocabulary for the fifth grade students.

2. After camp testing the experimental groups scored higher on eight of the ten comparisons. Five of the differences, all favoring the experimental group, were statisticaliy significant. They were: interest inventory for seventh grade students and nature study, vocabulary, arithmetic, and interest inventory for the fifth grade students.

3. The most striking result attained was the improved personal-social pelationships among the students as well as considerable learning about nature and outdoor living.

4. Reports of observations. Observers commented positively and favorably on the camping experience as providing a means of educational, personal, and soctal development vastly richer than the usual school program.

5. Pupli questionnaires showed the campers were overwhelmingly pleased with the outdoor experience and cited numerous instances of vital learning and social and emotional growth.

6. Parents enthusiasticaliy endorsed the program and favored its being incorporated in the regular school curriculum.

7. Teachers and supervisors involved in the experiment were in unanimous agreement that It was a significant experience that all school children should have (26).

"Cragg's study (12) attempted to determine the development of the sixth grade campers as compared with non-campers and to appraise the educational achievement of the camp program in terms of the educational school objectives. 
The tools of evaluation used by Cragg were the following:

1. Tests that include nature study and vocabulary, Two equivalent groups--experimental and control-were tested before and one week after the outdoor experience.

2. Essays. Camp essays were written before and after camp. Three professors read and rated the essays on a ten point scale with reference to spelling, vocabulary, style, Interest value, and number of activities mentioned.

3. Check lists of learnings. At the close of camp, 167 children checked the "things" learned at camp, the things already learned before camp, and the things not done or learned to do.

4. Soclograms. Campers named three best friends before and after camp, and four weeks later.

5. "Guess Who" responses. Pupils in the classroom named the aggressive children and the withdrawn chlidren before and after camp.

6. Rating scales. Counselors rated children on social growth and maturity. Warner's shortform soclalization scale was used before and after camp. Gains and losses were computed on a five interval scale for maturation of self-reliance, acceptance of responsiblilty, initiative, cooperation, mixing ability, efflciency, personal qualities, health habits, and participation.

7. Campers wrote down al1 the "things" that made them happy and a11 the "things" that made them unhappy lmmediately following camp and four weeks Iater.

8, Recordings. The last day at camp discussion centered around "What has this week meant to you?" Recordings were made and studied.

9. Questionnalres were sent to parents of campers to determine the learnings visible to the parent as well as a listing of the most valuable learnings. 
The general conclusions of the Cragg study were

outined as follows:

I. In spite of the shortness of the period, the one-week experience a't the Long Beach School Camp made some definite contributions to the educational development of the children according to the stated objectives:

A. Intellectual development

1. The children who had the camp experience showed greater Improvement than those who remained in the classroom.

2. The intense enjoyment of the chlldren might lead to pursuance of such interest in lelsure-time activities, but conclusion on this point can be merely conjectural.

B. The improvement of social relationships

1. The camping experience contributes to the Improvement of soctal relationships among children, but produces no change in certain aspects of the social development of some children, and causes losses in others.

2. Certain children maintain leadership and certain children remain social 1solates regardless of their environment.

c. The Camping experience produced a strong emotional impact in the joy and enthusiasm aroused in the children.

II. The experience holds elements of uniqueness common to many of the children, but the reaction to the experience is varied, individualistic, and enthusiastic. Experiences at camp which hold significance for the children tend to 
retain this significance over a period of time" (12, p. 31).

Johnson (12) 1955, attempted to: 1. Develop techniques to appraise changes in achievement, interest, behavior, and soclal status in junior high school students who had experienced one week of publle school camping. 2 , Establish criteria to evaluate the effectiveness of the appraisal techniques. 3. Apply each appralsal technique In school camping situations. 4. Evaluate the effectiveness of each separate technique.

The procedure to develop answers were sought in the following ways:

1. Ceneral 1iterature of general education as well as camping and outdoor education was surveyed.

2. Appraisal instruments were developed in conformity with established criteria.

3. Appralsal instruments that were developed were applied in the San Diego public school camping program. One group was experimental and the other was the control or non-camper group.

4. The Information elicited by these techniques was studied and evaluated.

The conclusions of this study indicate that changes do occur in pupil interest, pupil behavior traits, and 
group cohesion, but the assessment of these changes by the use of semi-objective techniques is of questionable practical value. The changes that occup in students' behavior may have long-term significance in the life of the pupil. The immediate evidence relating to change is toosubtle and Intanglble to be Identified by teachers' grades, an activity check Iist, a "guess who", peerrating questionnalre, or a sociometric questionnaire stuation (26).

Davidson (11) in 1965, used two encampments to conduct his appralsal of fifth and sixth grade students' self-concepts and soctometric status. Encampment I did not stress problem solving or were the students involved In any decision making. At very best, the student's involvement could only be described as a pseudo-democratic process, The adult leadership made most of the major decisions.

Encampment II was less structured. The students particlpated in the camp decisions. Group decision making, group discussion, problem solving, and creativity were all significantiy characteristic of this camp. The groups closely approximated each other in age, academic achievement, intelligence quotient, numbers, and sex. The students were also matched on the basis of their soctal-economic background. 
Before and after the outdoor experience each student was asked to complete these three evaluation scales:

1. Self-concept check 11st. The students were asked to mark the Ir response to statements under columns titled: This is very much like me; A little bit like me; Not like me at all. This scale was compoged of flfty-six statements: i.e., I have a good mind. I have little selfcontrol. I am afraid of many things.

2. Callfomia F scale. This scale was composed of twenty-nIne questions and the students circled one of six cholces: Strongly disagree; Disagree somewhat; Disagree a little; Agree a little; Agree somewhat; or Agree strongly. Examples are: Human nature belng what it is, there will always be war and conflict; People can be divided into two distinct classes, the weak and the strong; and, If people would talk less and work more, everybody would be better off.

3. Camper evaluation form, Almost always; Sometimes; and, Almost never; were the cholces given the students on this scale. This scale was composed of twenty statements e.g., I 
did the chores only because I was forced to do them. I feIt that I had the right to be an individual. I felt wanted and needed. The data gathered from this research demonstrates:

1. Children from lower soclo-economic backgrounds tend to respond "better" to camping programs that are highly structured.

2. Boys seem to adapt better to camp life than the glrls. Many girls remained apprehensive during the total camp session.

3. The structure of encampment $I$ produced significant differences in the students" responses to leadership than the structure of encampment II.

4. In both encampments some students showed a definite shift in response and some students showed no shift in response.

5. The over-all responses on the self-concept list of both encampments, when compared, showed little or no significant differences.

6. Students tend in a systematic way to respond differentiy to a check list given to them before and after an outdoor experience.

7. Outdoor experiences may be able to start, in some children, a process of change, both in 
personality and in attltudes toward age-mates and aduIts.

8. More investigation is needed in all aspects of outdoor education.

The Division of Curriculum and Instruction of the Milwaukee Public Schools in 1967, in order to evaluate their outdoor sohools, developed and administered questionnaires (30). It was felt that a series of questionnalres plus a pre and post test would evaluate the project's objectives:

1. To teach the elements of democratic living through group living, planning and sharing.

2. To provide direct experiences in the natural and blological sclences.

3. To teach the importance of and appreciation for natural resources.

4. To provide the opportunity for meaningful work experiences.

5. To teach sk1IIs involved in outdoor recreation, such as fishing, camping, boating and hiking.

6. To provide opportunities for fun and for students to assume responsiblitty and selfreliance.

A pup11 questionnalxe on the camping experience was administered to flve randomiy selected classes. The 
flve classes included 158 pup11s who had attended one of the camping sessions. The research design used to evaluate thlis project was of two types:

1. A one group experimental given a pretest and posttest.

2. Descriptive; using pupil, teacher, parent and administrator questionnaires.

An attitude scale was also devised to assess pupil attitudes toward camping skilis, self, peers, working together and the use of natural resources.

A questionnaire was sent to the parents of these 158 pupils in order to ascertain their feelings toward the outdoor experience, Twelve principals were also randomly selected to rate the project.

The data collected by the vamious questionnaires were analyzed by tabulating the response to sach question, Implications were then dram regarding the value and extent of the program by analyzing the consensus of opinion of the various groups questioned. These results are subjective In nature and may reflect personal bias, From an analysis of the data obtained:

1. Children Improved in social living, working together in small groups, and assuming responsibility.

2. Teachers felt a closer pupil-teacher relationship and were positive in their evaluation. 
3. There was Improvement in social development, home-school relations, and out-of-school activities.

4. Achievement and attitudinal changes revealed statistically significant, positive results.

5. This program is fulfiling its objectives and is making an impact on the lives of these ohlidren.

CONELICTING VIEWS

Not all camplng enthuslasts accept the notion inherent within the whole concept of outdoor group living, that soclal, emotional, and physical health will be affected in a positive way.

Rademacher (31), in his article entitled "The Child's Readiness for Camp", accepts the Idea that occasional separation of parent and child for the good of each is sound mental hygiene, but cautions that "the fact remains there are still far too many chlldren sent to camp who spend miserable days, not just merely homesick, but bored, rebuffed, Indifferent, and hurt, and have gained nothing from the expertence" (31, p. 135).

Gumprecht (22) warns that case studies investigating common emotional disturbances of chlldren at camp seem to indicate that some children, because of early social pressures may develop an unduly strict superego, and be 
forced into neurotic behavior patterns under the impact of increased soclal pressures of camp 11fe. Gumprecht and Rademacher do agree that camping is too valuable an experience to deprive any child of it. Improvements made by many chIIdren while in camp indicates that a therapeutic instrument is avaliable and that it is the adult's respongibility to make use of 1 . Gumpreoht also points out that it lis the task of the administrators to establish an snvironment that will help children form wholesome relationships and to make constructive and mature adjustment to reality.

Redl (32) also sexlously questions some of the conveyed values of camping. Discussing the psychopathologlcal problems of camping, he underscores some of the risks assoclated within our concept of democracy with Its strong belief in group Iife. He asserts that "Ilke all good things, even group Jife has its drawbacks and Iimitations". The adjustment to camp life, which must take place, is not always easy and often conflicts produced by the need for this outbalances the values to be derived from the camps accomplishment. For example Redl states that city children have heard about storms, animals, nature, and have used them as props in their day dreams and nightmares. What contacts they have made with nature usually were in broad daylight and under the 
guidance of their parents. Suddenly all nature is let loose on the student's half forgotten chlldhood anxieties, fantasy fears and real discomfort are mixed into a frightening blend. The result is that many children are frightened at camp most of the time. Redi was concerned, as was Gumprecht, with the child's "readiness" to proflt from a camping experience.

Harms (23) feels that the behavior testing in camp steuations by American psychologists of twenty years ago has done nothing more than to direct the original campIng impulses into a blind alley. Camping psychology under the conditions of test sheets, competition, and "good camping marks" was in reality a psychology whout a camper, He and his followers believe this first relationship between psychology and camping was wrong and almost tragic. Harms suggests that only recently has there emerged a real camping psychology which emphasizes the fact that real camping psychology does not grow from the physical, nor even from the mental camping needs as perceived by early camping psychologists. He bases hil new psychology in the "troubles" of even a falrly nomal child who comes from a city environment, parental protection, or overprotection. According to Harms, this new camping psychology deals with the real child and attempts to see the psychological problems which arise on all sides. 
Hams concludes, In regards to camping Ilfe itself, we mist consider not only the individual aptitudes of each child but also his reaction to the new enviloninent and his assimilation of the factors offered as being healthel. Several different types of camps suggest themselves, Which mat include in the r program psychologlo supervision as we11 as educational assistance. 


\section{REIATED READINGS}

The related readings selected for this section represents some of the research that have been conducted In the area of self-concepts. They wexe chosen for their relevance to the present study and for there methodological implications.

Gladys Jenkins $(17$, p. 2.) points up the fact that so often a child's plcture of himself may not be a true one. His self-concept may have come to him through grownups who themselves see him through blinders. This author also reminds us that only as a child leams to Ilke himself can he reach out successfully into the school and the community.

Ira J. Gordon (17) In a series of artioles; "The Role of Self-Estimates in Behavior," How Self-Concepts Come About," and "How Adults Can Estimate Children's SelfConcepts," discusses individual ways in which children develop their concept of "the self."

She states that self-concepts are constantly formIng and that any single, speciftc concept is not formed by a single event; it is the result of the mixing of many forces, physical, environmental and psychological, Since the child is growing and is constantiy being exposed to new experiences his "self" is not static. It 
Is constanty in the process of organizing, af taklng on new feelings, attltudes, and ldeas. Self-concepts are affected by growth and experience and are influenced by forces acting upon the child as well as being forces themselves $(17, \mathrm{p}, 8)$.

Gordon also feels when youngsters reach the preadolescent years that the importance of adults as ghapens of attitudes diminishes. What the "gang" or peers think of him aseumes lncreasing significance. Youth, at this age, are noving toward independence from adults and since they are not mature enough to really be on their own, they use the "gang" as a source of strength in woxklng through their new relations with adults. "These groups," state Gordon, "also serve as places where exploratory needs can be met, where infomation can be exchanged, and where Ideas and ski11. can be tested" (17, p. 15). These early years are of vital importance in setting the general direction. School and peer experiences act to supplement the original concepts. Many children who lack the ski11s that adults value are able to achieve in those areas of Ilfe which peers value $(17, p, 16$.$) .$

The au'hor, in his summary, sees the aduIt as an estimator of the child's self-concepts but in doing so should ask himself two questions as a way of beginning 
to see the child as the child sees himself. "First, how must the child be percelving his situation at the moment that causes him to believe this behavior is right? Second, how must he f'eel about himself?" (17, p. 24).

From a review of more than 300 published studies and 120 unpublished doctoral dissertations, Wylie (10) concluded that research evidence about selfmooncept supports the following generalizations:

1. One's self-concept is shaped through interaction with others,

2. One's self-concept influences his interaction with others.

3. A child's self-concept is almilar to the view of himself which he attributes to his parents.

4. One's body characterlatics which are highly valued enhanoe his self-regard; his body characteristics which are lowly valued undermine his self-regard.

5. The extent to which faliure or success changes one's self concept is tied up inextricably with: (a) Certain personality characterlstics, (b) The extent to which one values the source of his fallure or success. (c) The extent to which he feels that the source of information is viewed as adequate. 
6. Social desirability in our culture is seen as having much in common with health over sickness, wel1-being over maladjustment. The influence of social destrability is so great that one must be confronted with the "Ideal Self," and the "Actual se1f."

According to Combs (1a, p. 50-54) a child may see himself in many ways according to the structure of the situation in which he finds himself. Feelings of worth must be supported by positive interaction between himself and others.

Maslow $(6, p .3)$ presents these assumptions concernIng the self:

1. Each of us have an essentlal blologically based Inner nature, which to some degree is "natura1."

2. Each person's inner nature is in part unique to himself.

3. This inner nature is good or neutral rather than bad.

4. This inner nature is not strong and overpowering, it is weak, delicate, subtle and easily overcome by habit, cultural pressure, and wrong attitudes toward 1 t.

He also presents forty-three "self-psychology" propositions important to the educator (6, p. 177-200). 
In summation of these propositions he points out it is best to bring out and encourage, to recognize this inner. nature, rather than to suppress or repress it. The chlid must give up being good out of fear and must be good because he wishes to be, He must discover his own conscience and glve up his parents as the onIy ethical guide.

Sears $(7, p, 10)$ sees the child making judgments about the self in relation to problems and tasks of development. The self-concept represents expected success to meet these problems and tasks. The self-concept is complex, made up of many "facets" with each differing in importance from the others. Expectancles are learned from these facets so the Individual can predlet success or fallure in connection with behavion that pertains to a given facet. Expectancles that have been acquired can be changed according to "princlples of learning." One will strive hard to protect a good self-concept and will select those behaviors which preserve or enhance 1 t.

"The opinion an individual has for himself is clearly an important component of his behavior", says Stanley Coopersmith (18, p. 86-107) In his study on self-esteem. Using teacher's reports, clinical tests, interviews with parents, and self evaluations the author and his assoclates reported these findings conceming self-concepts in middjeolass, urban boys, age 10 to 12. 
1. Children with a high degree of self-esteem are expressive Individuals and tend to be successful both socially and academically.

2. They show little destructiveness in early childhood and are little troubled by feelings of anxiety.

3. They appear to tmust their own perceptions and have confldence that their own efforts will meet with success.

4. They are 1eso equently afflicted with fatigue, headaches, insomnia, and intestinal upset.

5. They tended to be optimistic, expressive, and able to take critulolsm.

In contrast to the boys with high esteem the boys with low self-estem:

1. Presented a pleture of discouragement and depression.

2. They felt isolated, unlovable, and incapable of expression themselves.

3. They were fearful of angering others and felt fearful of exposing themself.

4. In a group they remained in the shadows, sensitive to criticlsm, self-conscious, and preoccupied with inner problems. 
The author's exploration of the factors that lead to the development of high self-esteem in children produced a number of contradictions of popular beliefs,

1. No consistent relation between children with high self-esteem and physical attractiveness, the size of the family, or the occupation of the mother were found,

2. The indlvidual with a high self-esteem is almost as high in low soclal classes as it is in the higher social classes.

3. Children tended to gauge their individual worth primarliy in theif own interpersonal environment.

Looking Into the backgrounds of the boys Coopersmith notes that the boys with high-esteem experienced welldefined constitution for behavior but also by a democratic spirit. The parents established the princlples and defined the powers and responsiblilties. The parents showed deep interest in the children, they were open to persuasion and wlling to allow the chlldren a volce in the making of famlly plans, The guidance provided by well defined rules of expected behavior, the nonpunitive treatment, and respect of the chlidren's vlews contributed greatly to the boy's high self-esteem.

The findings from these studies indicate that children develop gelf-trust, venturesomeness and the ability to 
deal with adversity if they are treated with well-defined standards of values. It also appears that the development of Independence and self-rellance is fostered by a wellstructured, demanding environment rather than an unlimited permissiveness in an unfocused way. In conclusion, the author invites further exploration into the rules and limits on behavior that can contrlbute most effectively to build youngster's self-esteem,

In summation of some of the related readings Kelly (1a, p. 9-20) states that the self has to be achieved, that is, It is not given. The child is given the "equipment" and the environment but the self is achieved through social contact which has to be understood in terms of others. Masiow (1a, p, 34-39) feels if given a chance the normal chlla under normal conditions, if given a free choice, will ohoose what is good for his growth. This "Implles" that the child knows better than anyone elge what is good for h1m. The "self" grows into adulthood only partly by discovery or uncovering and acceptance of what is "there" beforehand but partly the self is a creation of the person himself.

Combs (1a, p, 50-63) sets forth the proposition that chlldren learn who they are and what they are from the ways In which they have been treated by those who surround 
them. The self, as we know it, is leamed, Children discover their self-concepts from their experiences and not from telling.

Even though the outdoor school has become an important addition to the basic school curricula, there is still lack of agreement concerning the impact of this axperience on the emotional well-being of children. The major purpose of this investigation will be to determine If there are any consistent and prolonged changes in chlldren's self-concepts and their attitude toward the natural environment after taking part in an outdoor school for a given period of time. 
Camp Colton, located in Colton, Oregon has served as a base for the Regional Outdoor School for the past three years. Classes of sixth graders attend this school during the months of September, October, April, and May. Usually four sixth grade classes attend the outdoor school at one time. The students arrive on Sunday evening and depart Friday aftemoon of a given week. The encampment is highly stmuctured, that is, the aduIt leadership makes all the major declaions. The students are not involved in any of the camp's planning sessions and have very little unstructured time. See Table 1, "Dally Schedule and Bugle Calls" and the "Weekly Schedule," Table 2. Development of Instruments

Seeking an instrument which would examine selfconcepts a systematic study of words and terms used by slxth grade students was explored. One-hundred and eight sixth grade boys and girls were asked to respona, in writing, to the question, "What word or group of words would you use if someone were to ask you to talk about yourself?" Appendix A show the form that was used. Appendix B shows a list of the words and the frequency that each word ocourred. 


\section{TABIE I}

DAILY SCHEDULE AND BUGLE CALLS

\begin{tabular}{|c|c|c|}
\hline $7: 00 \mathrm{~A} . \mathrm{M}$ & Bugle & Reve111e \\
\hline $7: 20$ & Bugle & Chopsticks, Flag \& Weather Crews Report \\
\hline $7: 40$ & Bugle & Moming Colors \\
\hline $7: 50$ & & Breakfast \\
\hline $8: 30$ & & Daily Duties \\
\hline $8: 50$ & & Cabin clean-up \\
\hline $9: 15$ & Bugle & $\begin{array}{l}\text { Inspection of Cabins - Cabins clear } \\
\text { of people }\end{array}$ \\
\hline $9: 30$ & & Field study \\
\hline $12: 00$ Noon & Bugle & Chopsticks Report to Dining Hall \\
\hline $12: 15$ P.M. & & Noon Mea I \\
\hline $1: 15$ & & Quiet Time \& Showers \\
\hline $2: 00$ & Bugle & F1eld Study \\
\hline $4: 45$ & Bugle & Recreation \\
\hline $5: 45$ & Bugle & $\begin{array}{l}\text { Chopst1cks, Flag, \& Weather Crews } \\
\text { Report }\end{array}$ \\
\hline $6: 00$ & Bugle & Evening Colors \\
\hline $6: 15$ & & Evening Meal \\
\hline $7: 15$ & & $\begin{array}{l}\text { Teacher Evaluation with Students \& } \\
\text { Junior Counselor Evaluation }\end{array}$ \\
\hline $8: 00$ & Bugle & Camprire \\
\hline $9: 00$ & & Bedtime \\
\hline $9: 15$ & Bugle & Tattoo \\
\hline $9: 20$ & Bugle & Taps \\
\hline $9: 30$ & & $\begin{array}{l}\text { Staff Briefing - Director meets } \\
\text { with Sr. Counselors, Resource } \\
\text { Coordinators, Teachers, and } \\
\text { Junior Counselors }\end{array}$ \\
\hline
\end{tabular}




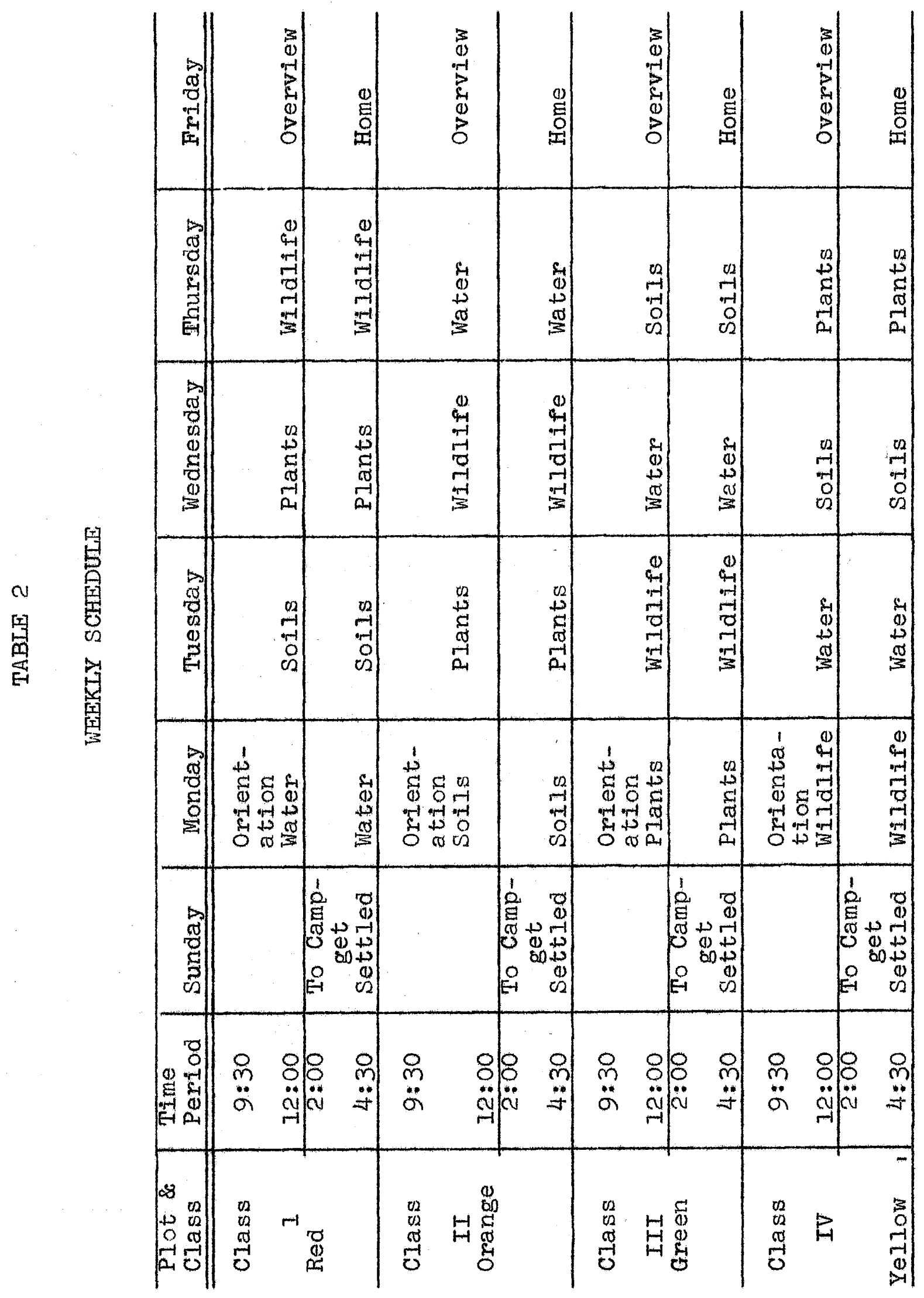


From this initial survey a list was conplied using only the students' words or terms, Appendix $C$. One hundred and five other sixth graders, from different schools, were asked to check each word that they would use when talking about themselves. Next to each word is a number representing the frequency with which each word was marked.

An ltem analyals of the words submitted by the students was made to select those terms or words most commonly used. Then, after a study of the related research, observations of chilaren in conversation, and consulting with specialists in the fleld of reading, the students' vocabulary responses seemed suitable for uge in devising two concept scales:

1. Concept Scale I, Appendix D, summarizes what the student thinks of himself.

2. Concept Scale II, Appendlx E, surveys what the student thinks others think of him.

To determine the coefficient of rellability of these two scales they were administered to twenty-five sixth grade students on successive days. The test.retest method was used $(1, p, 80)$. Concept scale I has a reliability of .65 and Concept Scale II has a reliab111ty of 85 .

In searching through the literature for unstmetured methods of exploring attitudes, one frequently came across 
41

reference to the incomplete sentence test (7). Its

advantages lie in the lack of rigid "yes" or "no" answers and seemed valuable as a device for eliciting attitudes toward the natural environment.

Exploring the thinking behind the incomplete sentence test a diary was constructed on multi-colored $5 \times 8$ cards. Approximately ten lines were drawn on each card. The diary consists of forty-five pages. On the front page the words, "This Diary Belongs To w_, was printed. On the next page, near the top left corner the words, "Your comments" were inscribed.

It was expected that a content analysis of the unsollelted comments of the students, one week before the outdoor school, the week during the outdoor school, and a follow-up of one week after a return to the classroom would yield data which would serve to validate answers related to the attitude scale. In this way the total scales would serve as an integrating force which would establish rellability as well as valld1ty for the data revealed in ali three scales, The students at Holy Redeemer School partlolpated in this phase of the study, An attitude scale was designed to reflect the chlldrens' feelings toward the natural environment. By using the subject matter areas taught at the Regional Outdoor School; soll, wlldile, plants, water, and man, (34) 
It was ascertained that a scale could be developed that would Indlcate and measure the child's feelings. In other words, the students would have to respond to statements that reflect an attitude toward the natural environment. In the self-rating column the students were asked to plck one of three responses; "care," "don't care" or "am undeclded." Since children of this age tend to pick a midale response, or to rate themself average, it was felt that this method would give a better distribution of scores. The responses labeled "care" 1s given a score of 3: "don't care" 1, and "àm unđecided" a score of 2. See Appendix F. A high score would indlate a favorable attitude toward the natural environment. By using a testretest method the rellablitity coefficlent of this scale was calculated at .87 (1, p. 80).

After analyzing the responses given by the testretest groups 1.t was felt that satisfactory results were obtained. Very little or no revision was necessary.

These three scales were administered to the groups two weeks prior to and slve weeks after the outdoor experlence by the researcher. It was expected that Individual and group analyses would be made of the types of responses made by the particlpants. 


\section{CHAPTER V \\ ANALISIS OF DATA}

All four classes were administered the attitude scale and the two concept scales two weeks before and five weeks after the outdoor experience. An individual 1.tem analysis, Tables 6 through 17, was tabulated on each class. A school, group analysis, for clustering of the responses was also complied showing the means, Tables 3, 4, and 5. In the present investigation it was felt that any consistent difference between the pretest scores and the posttest scores should reflect the Influence of the outdoor school. Attitude scale toward the natural environment

Can a six day outdoor experience exert a difference on the attitude of sixth graders toward the natural environment? How does a student at th1s age feel about hls responsibilities in regards to natural resources? In order to probe further into these self-centered questions an attitude scale, using sixteen items, was employed, Appendix $\mathbf{F}$.

One of three responses was possible: "I care," "I don't care," and "I'm undecided." A numerlcal value of three was given to the flust response, one to the second, and a value of two to the "undeclded" cholce. A shift from a higher number to a lower number was recorded as a negative move and a shift from a lower number to a higher 
number was considered as a positive move. This procedure was in accord with the statistical process applied to the data.

The number differention of shifts on each student and on each item for the four schools were recorded, Tables $6,9,12$, and 15. It was assumed that shifts due to chance factors would be equally divided between the positive and negative responses. As is usual, and this also applies to the other two scales, when scores are already high in the pretest it is difficult to show a gain In the posttest.

There are many research situations in education and psychology which involve the correlation afference between two means. The situation chosen for this study was one of correlated samples, that is, the members of two sample groups may be paired on the basts of one or more characteristics such as a pretest and posttest. This correlated design may be evaluated for a significant difference between the two means by the formula

$$
t=\frac{x_{1}-x_{2}}{\frac{d^{2}}{N(N-1)}}
$$

where $d^{2}=D^{2}-(D)^{2}$. The $N$ is the number of pairs 
and $D$ is the difference between the scores for each pair. The expression $x_{1}-x_{2}$ is equivalent to (9a. p. 141).

Concept Scales I and II

The method used in attempting to identify change in self-concepts follows an assumption that consistent changes in the way chlidren feel about themselves would be reflected by conslstent changes in their responses. The pretest provided a basis from which the results of the posttest could be compared. The Individual change that took place during the slx weeks between the first and second administration of the scales are presented in Tables $7,8,10,11,13,14,16$, and 17, One of the important questions to be answered in this study is whether changes resulting from the outdoor experiences are malntalned after a considerable time lapse.

One of three responses was possible in concept Scale It "This is very much like me, "given a value of three, "A Ilttle bit like me," given a value of two, and "Not like me at a11," given a value of one. A check in the frst column on 1tems $3,4,6,7$, and 14, would mean a reversal of the above procedure, Appendix $D$. Tables 7, 10, 13, and 16 11lustrate the individual change for each student and each 1 tem. 
In Concept Scale II, Appendix E: "Most of the time" was given a value of three, "Some of the time" a value of two, and a value of one was given to "Seldom." A check in the first column on 1 tems 11 and 15 would mean a reversal of this procedure. Consequentiy, in some cases a negative shift was statistically a positive one. This seems to be in IIne with good test procedure, since negatively worded 1tems may tend to remove a degree of suggest1b111ty and to minimize the tendency of subjects to check a single column that seemed always to indicate the best answer. Since all the data have been tabulated In positlve and negative shifts the reader need not conslder the dipection of the wording of any 1tems in interpreting the meaning of the data.

The number of positive and negative shifts on each Item for the four schools were recorded, Tables 8, 11, 14, and 17. A group analysis was also oomplied for each sohoo1, Tables 4 and 5. The .05 level of signiflcance was chosen since it is conventionally accepted as the levei of probablitty for rejecting a null hypothesis. Statistica11y, no attempt was made to differentiate between individual items.

The posa1b111ty was always present that the subjects might attempt to distort their answers on the instruments. 
Since the children were asked to put theirs names on the acales this chance of distortion may have been increased. The researcher suggests that any distortion that might occur would be irrelevant because the purpose of the research was an attempt to study changes in self-concepts without specific regard to the students correspondence with reality.

The posslbility may still remain that the children misrepresented their feelings about themselves. If this were a consistent factor, Its influence would tend to be canceled out, since the data measured only shifts between totals rather than responses on any single item. Table 18 is a compliation of the $t$ scores on the Attitude and Concept scales I and II. 


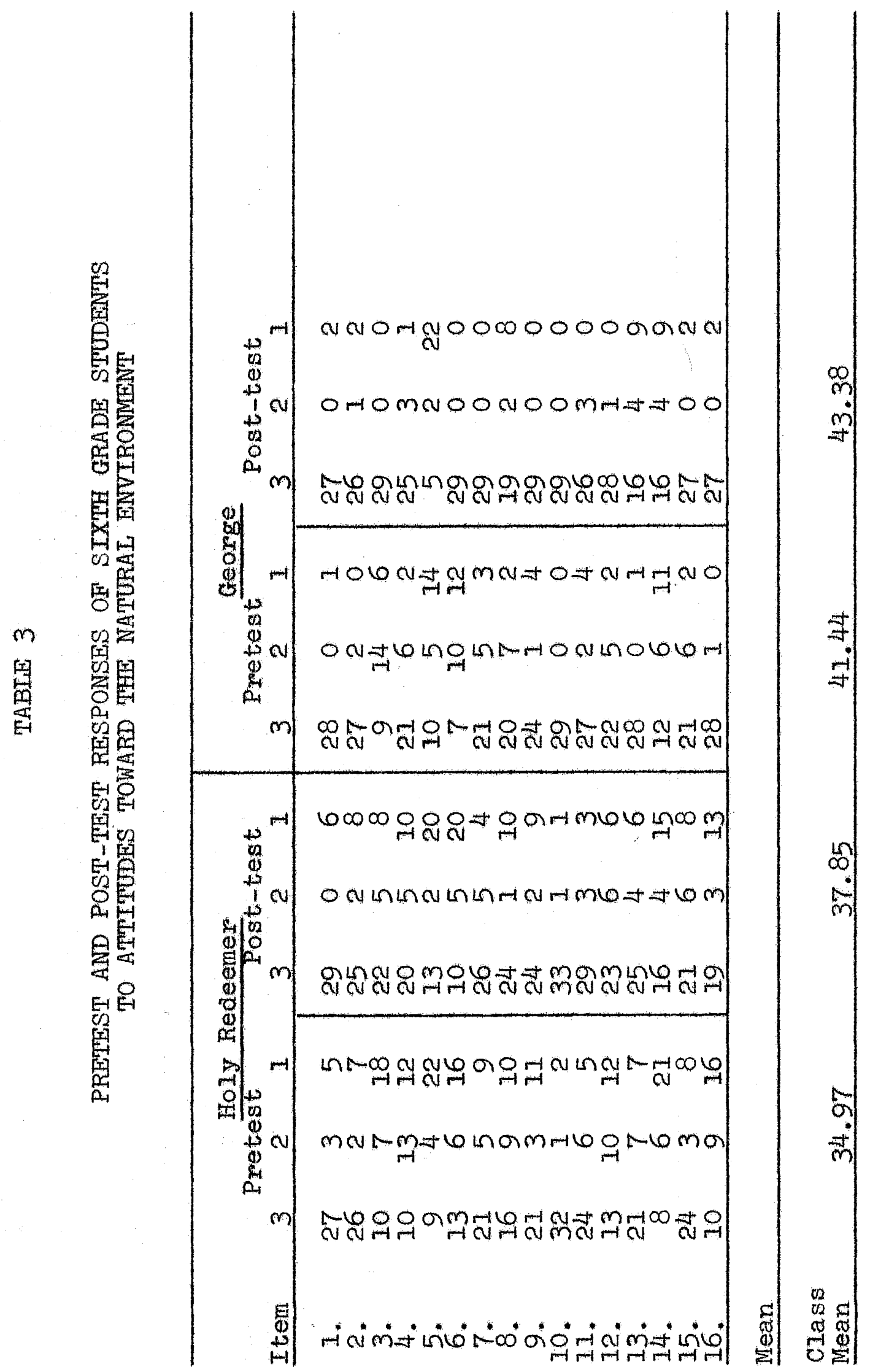



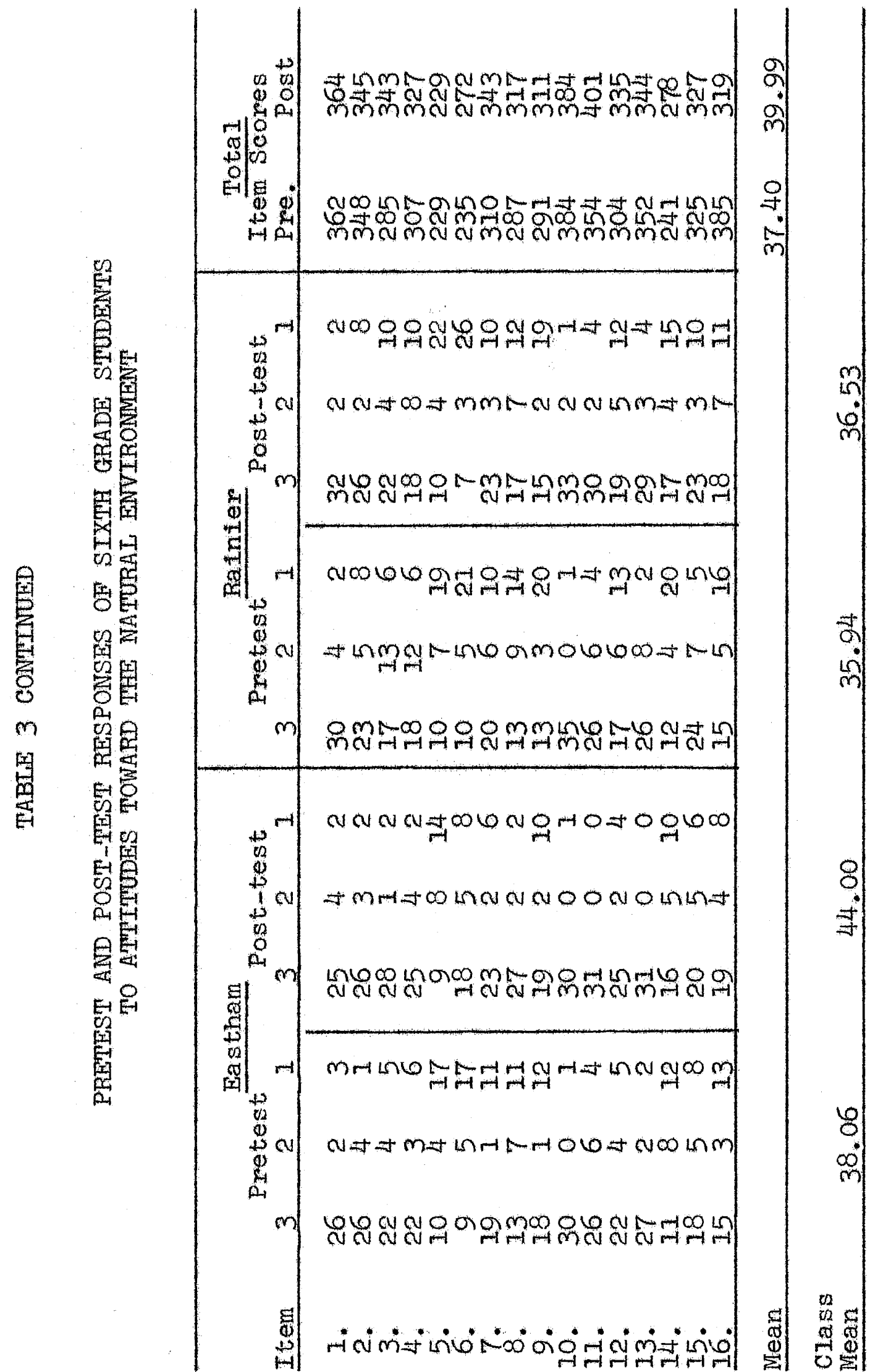


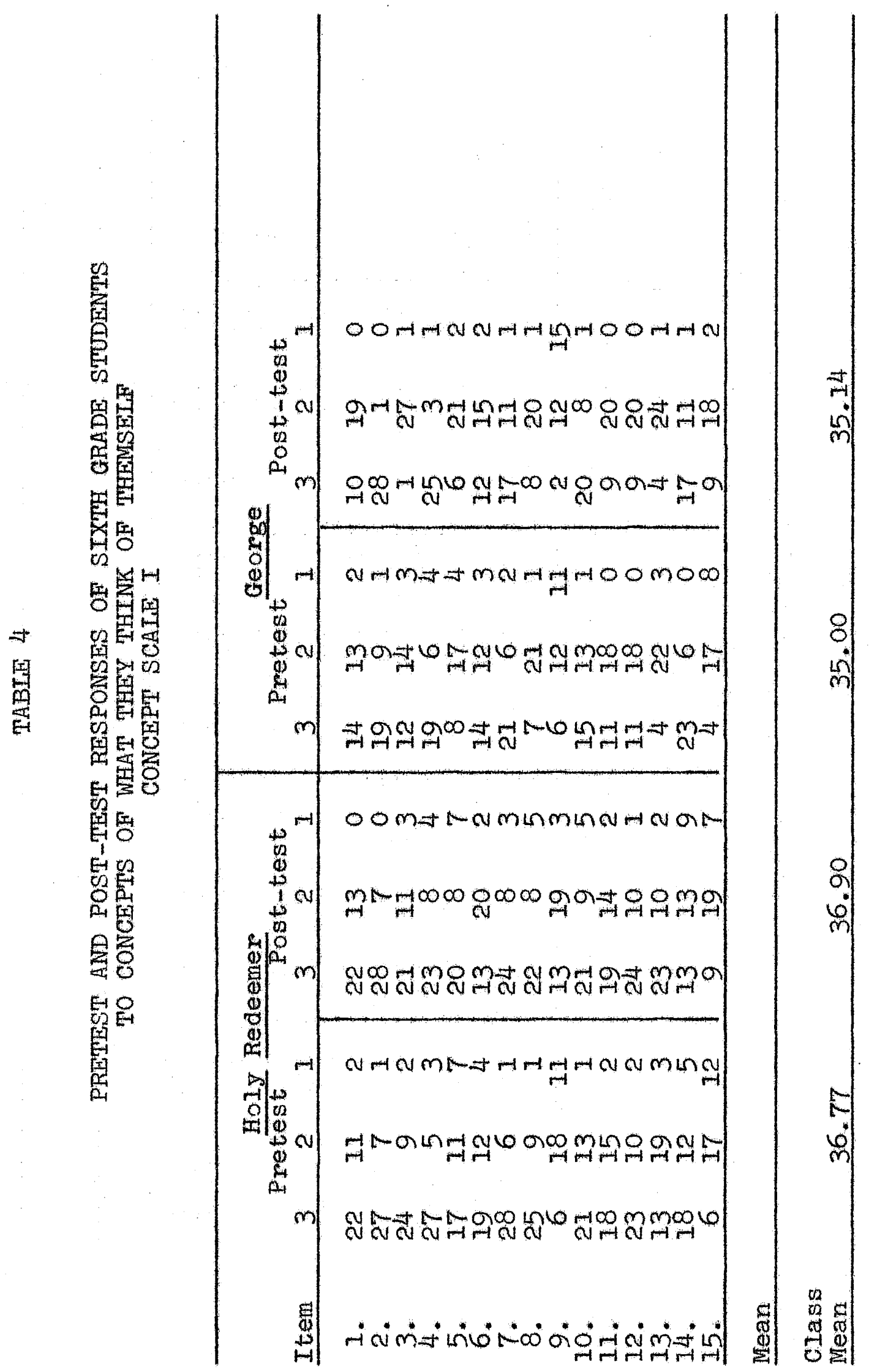




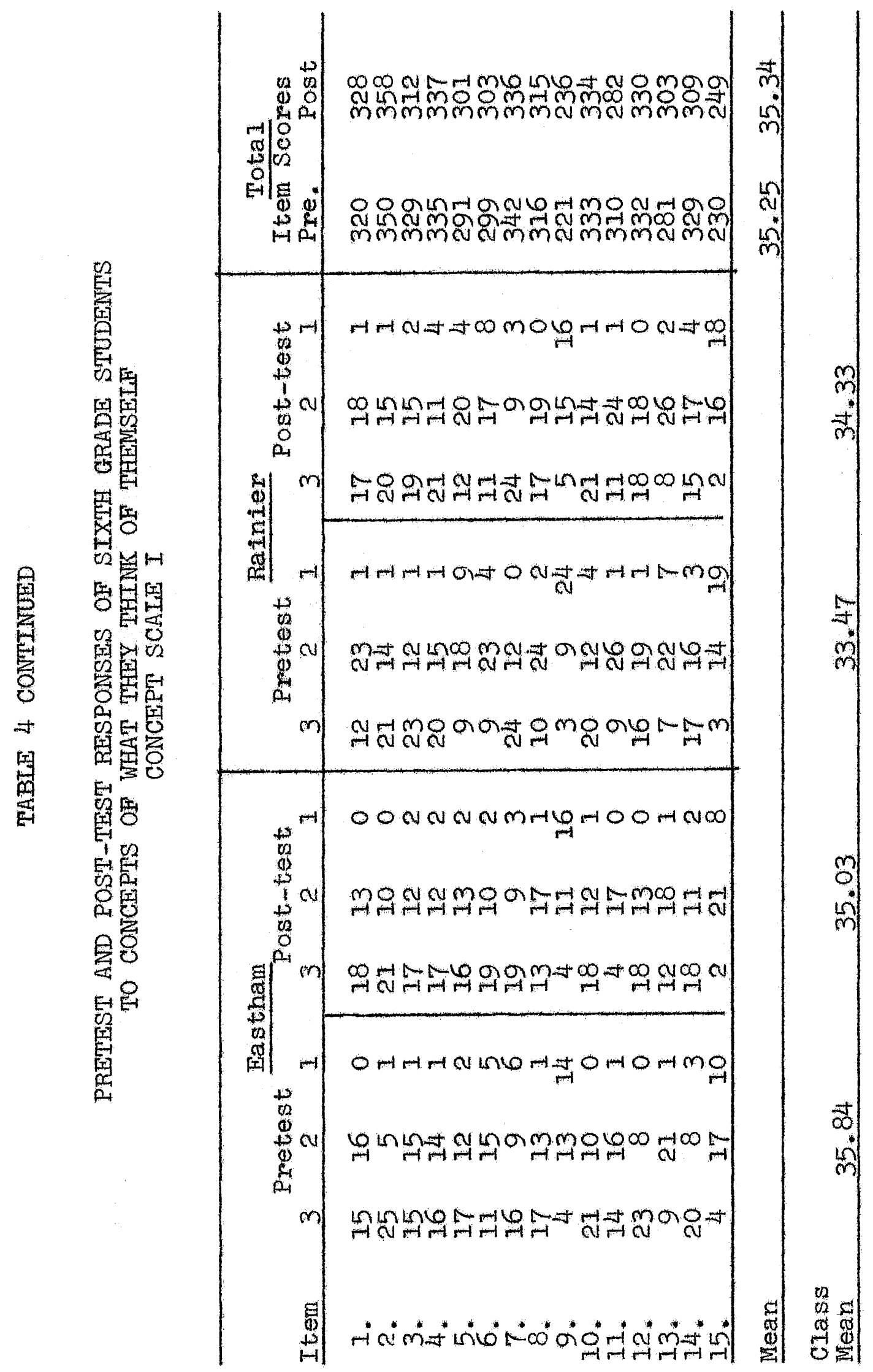




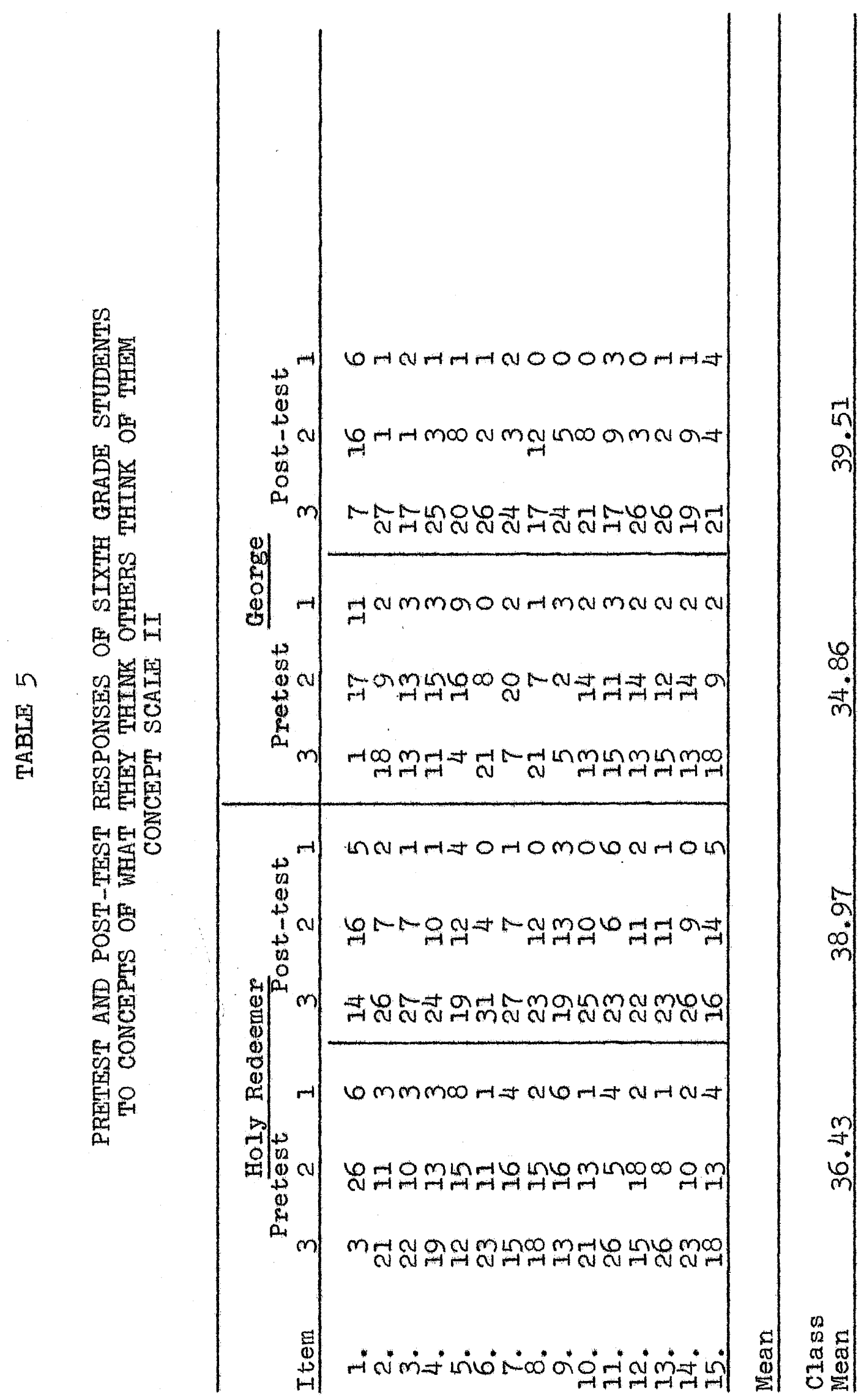




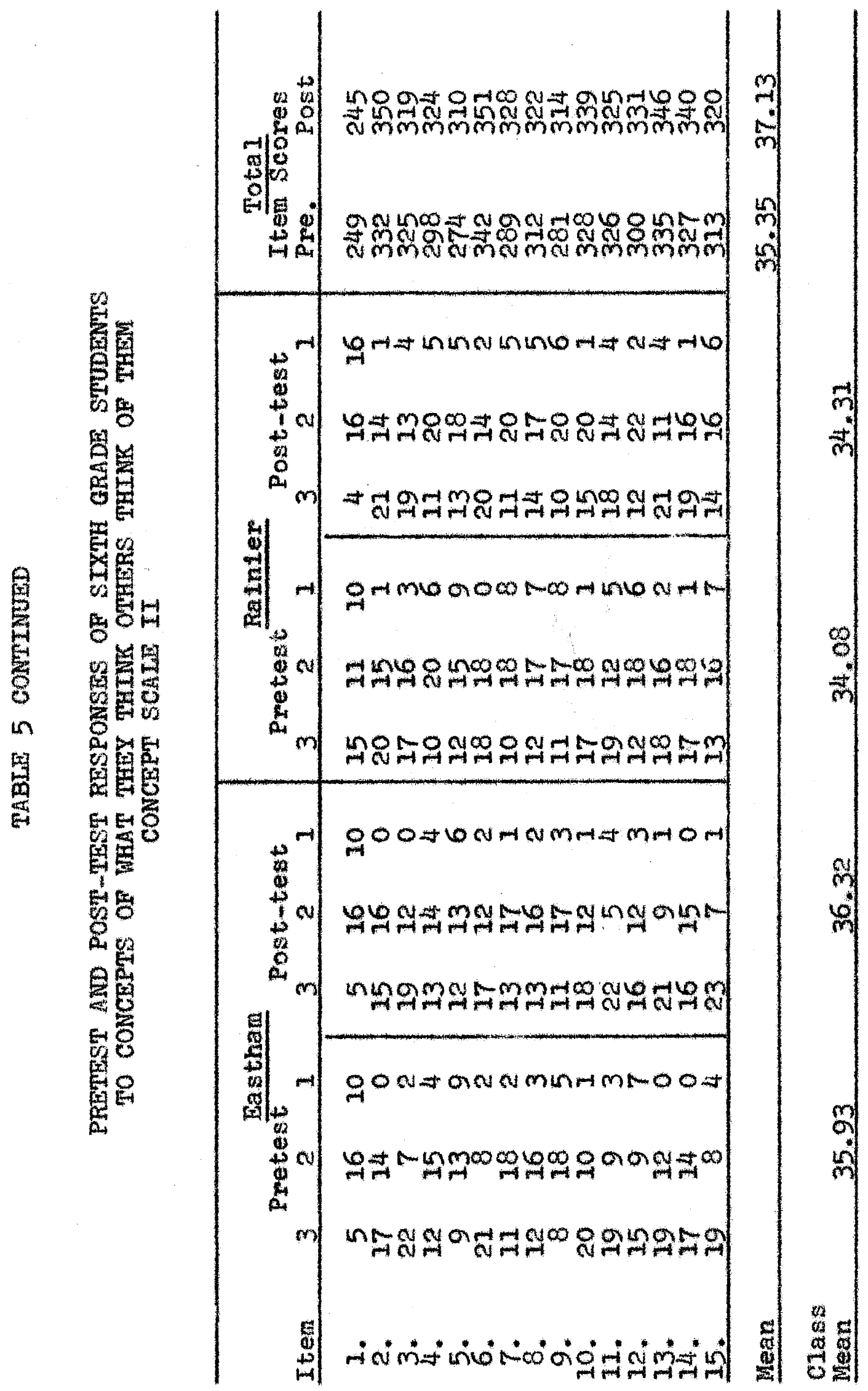




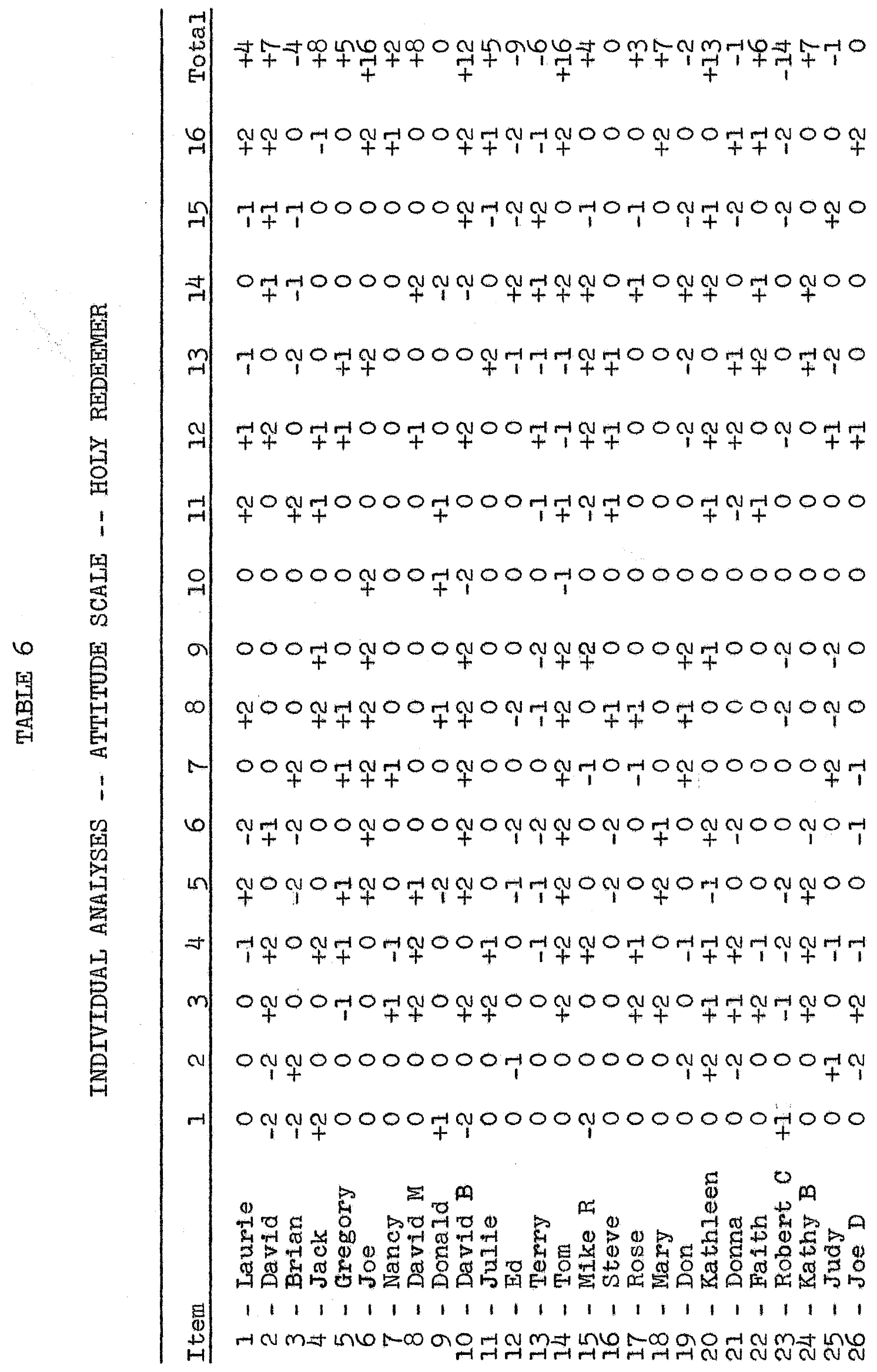


कinmprommog

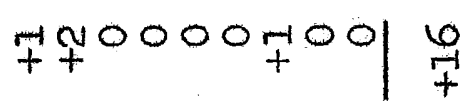

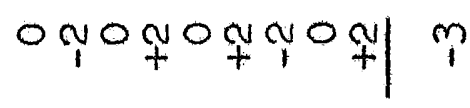

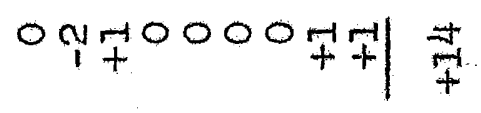

ThOHOONOO

0000700 T⿻

ONOOOFOT T

星 0000000 인

完

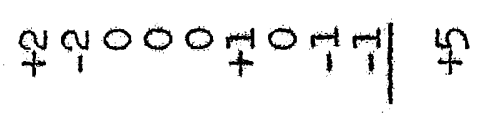

0 to007000 年

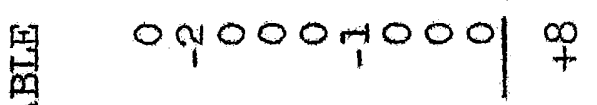

E ONONOFO유 T

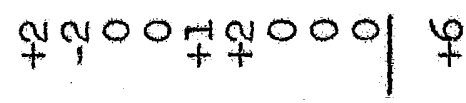

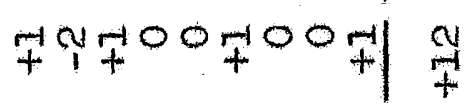

क⿻十

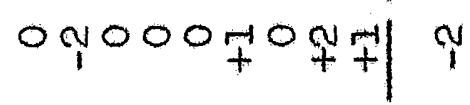

000000 WTW 7

य2 020

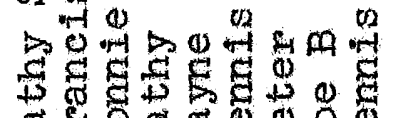

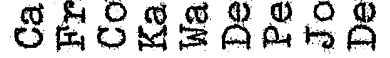

禹

11111111

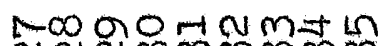

त $\mathrm{N}$ जलmmmm 


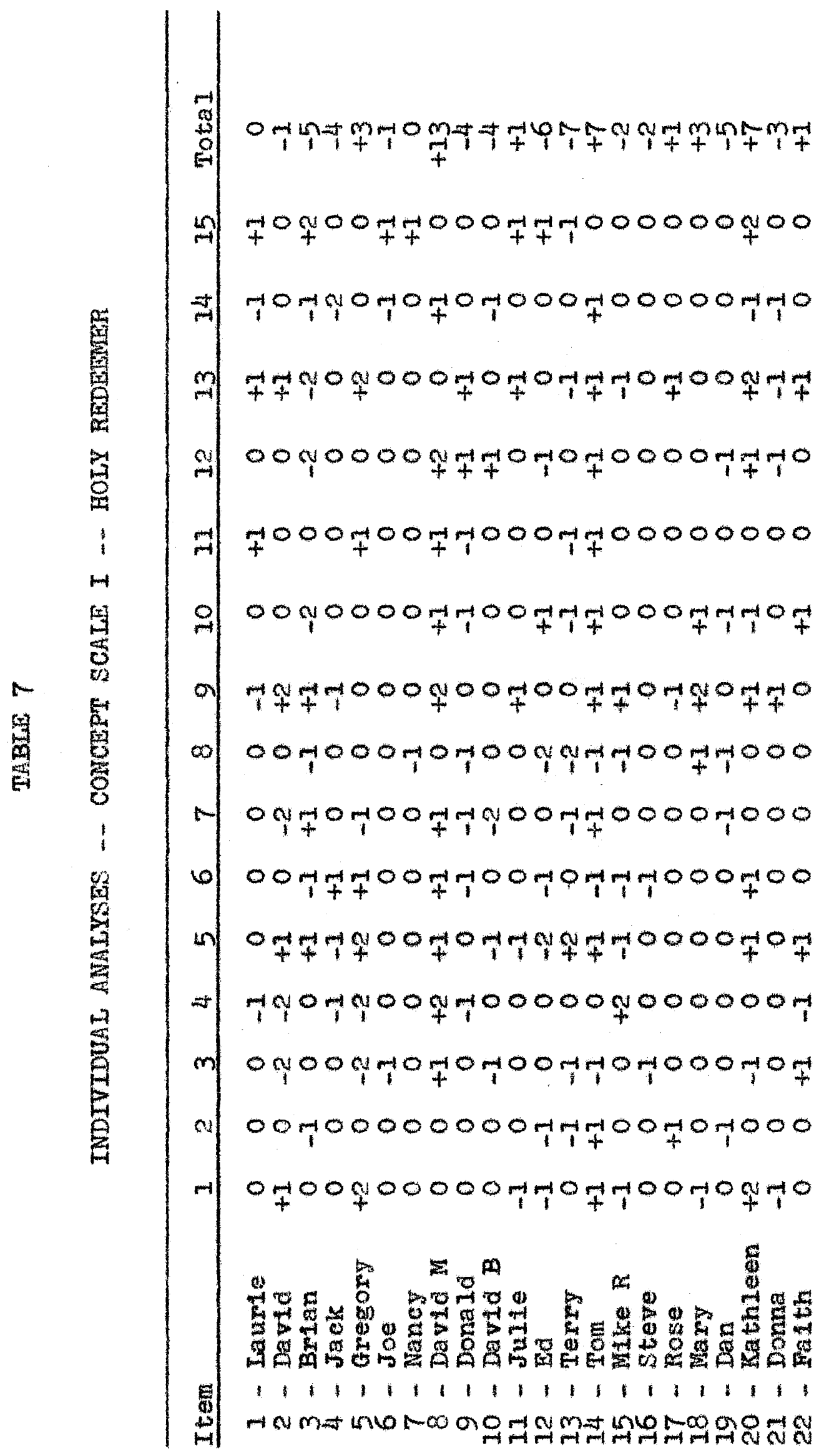




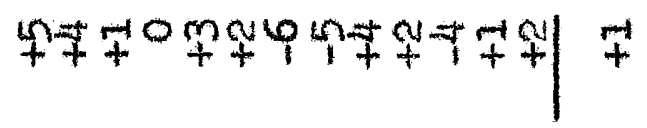

700704700\%000

to00007q7y

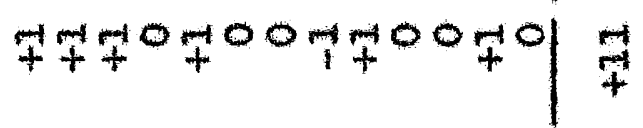

O०

$0000000007000 \mid 7$

8

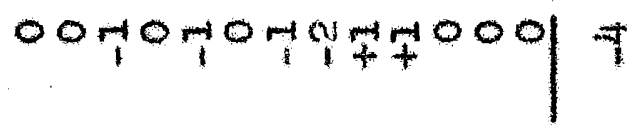

$0070707007000 \%$

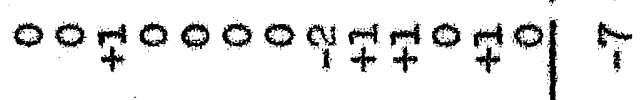

000000 10000\%임

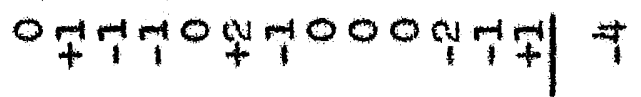

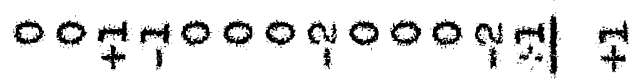

om

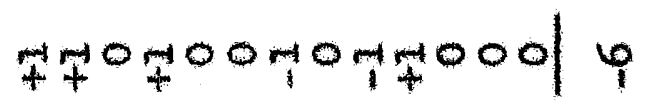

000 tFTH

$7000007070000 \mid q$

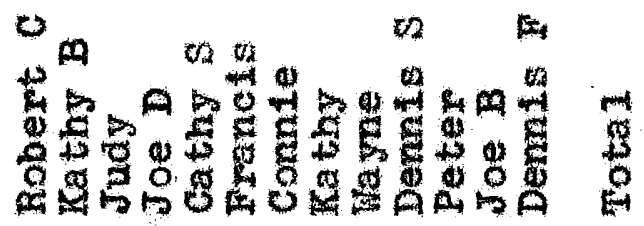

$1+111111111$

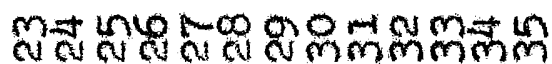




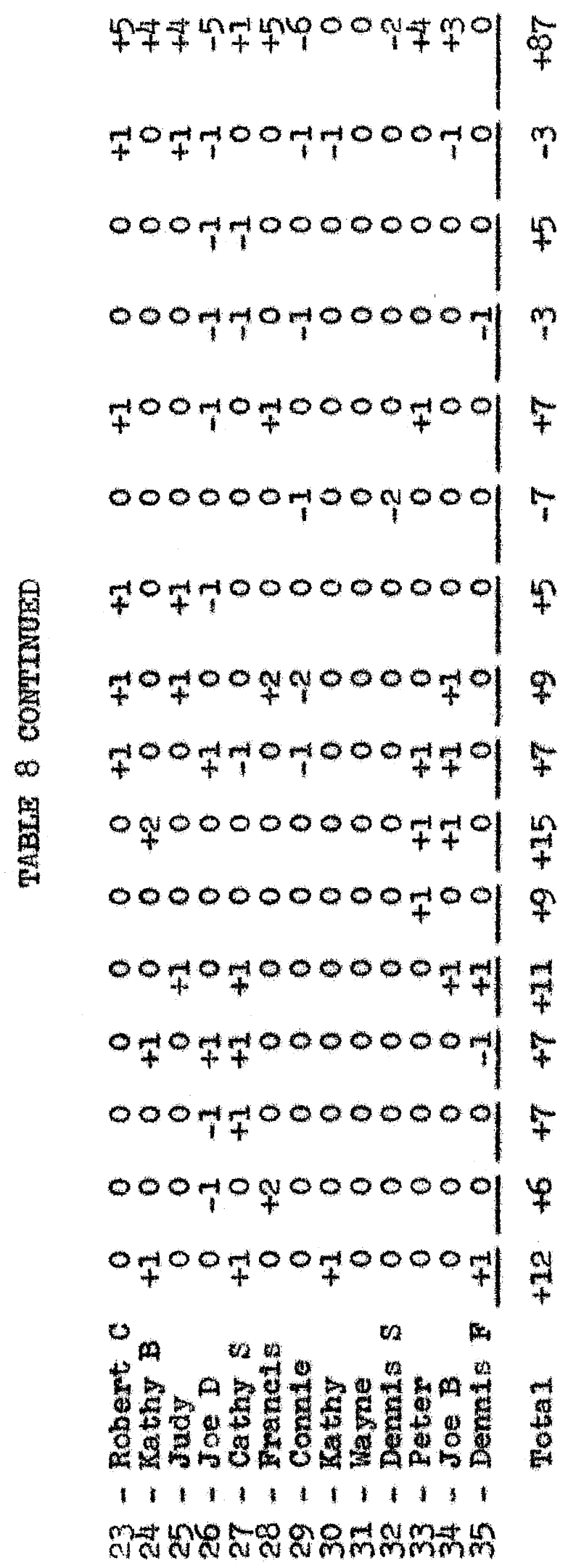




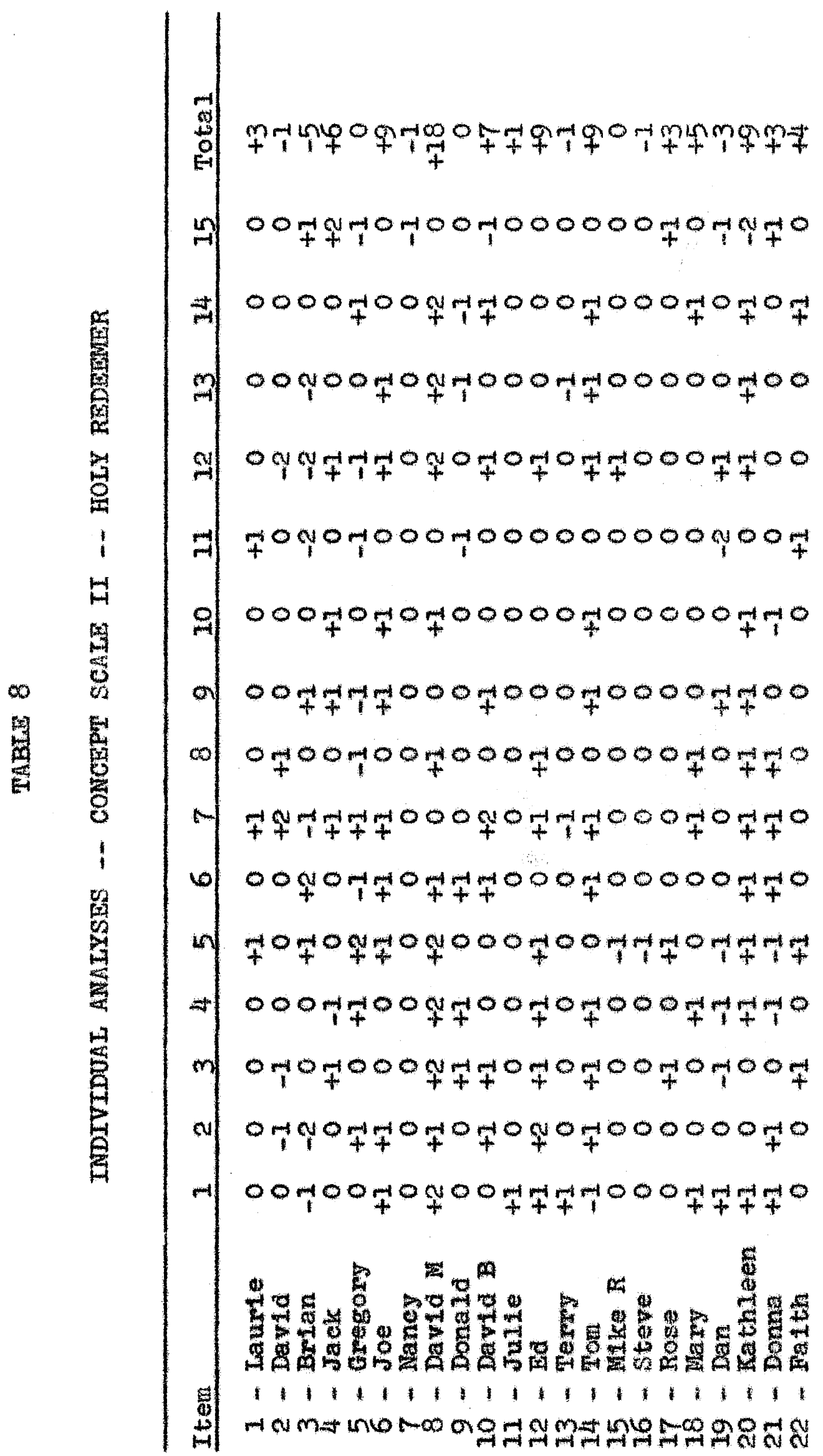




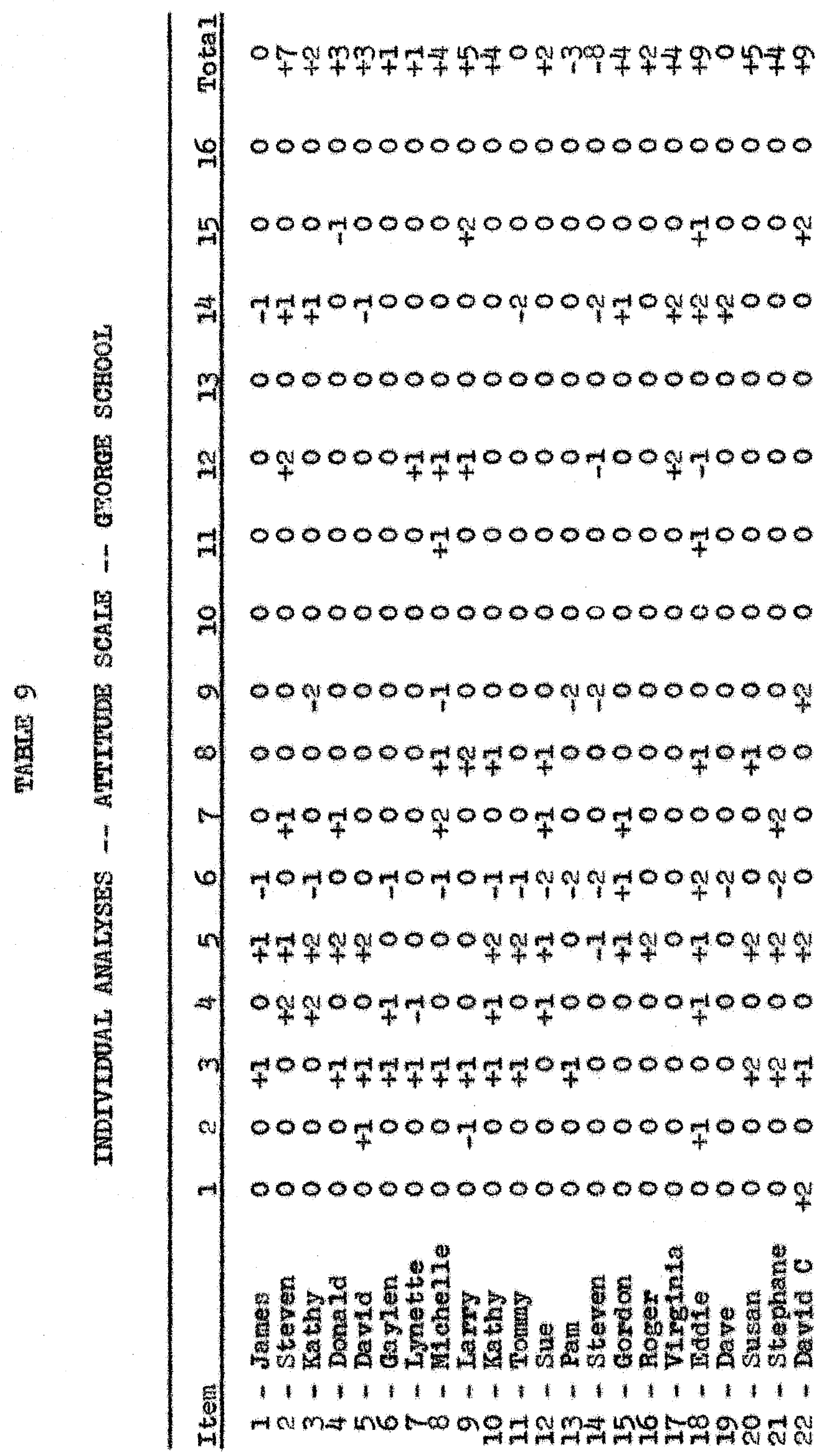




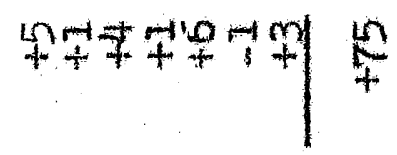

oogyotom

아단t하이 운

o.

oogomool 4

0000 to의

00000004

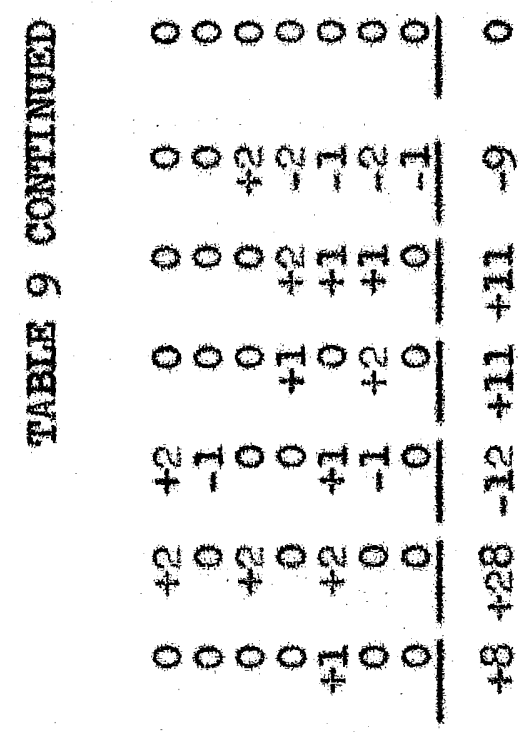

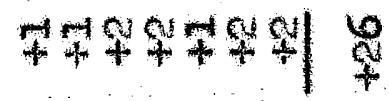

oopoogly

o요에

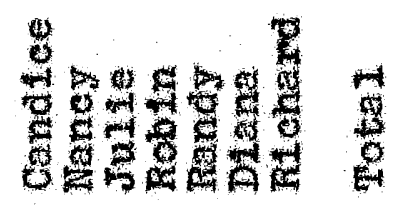

$11+11$

mat 


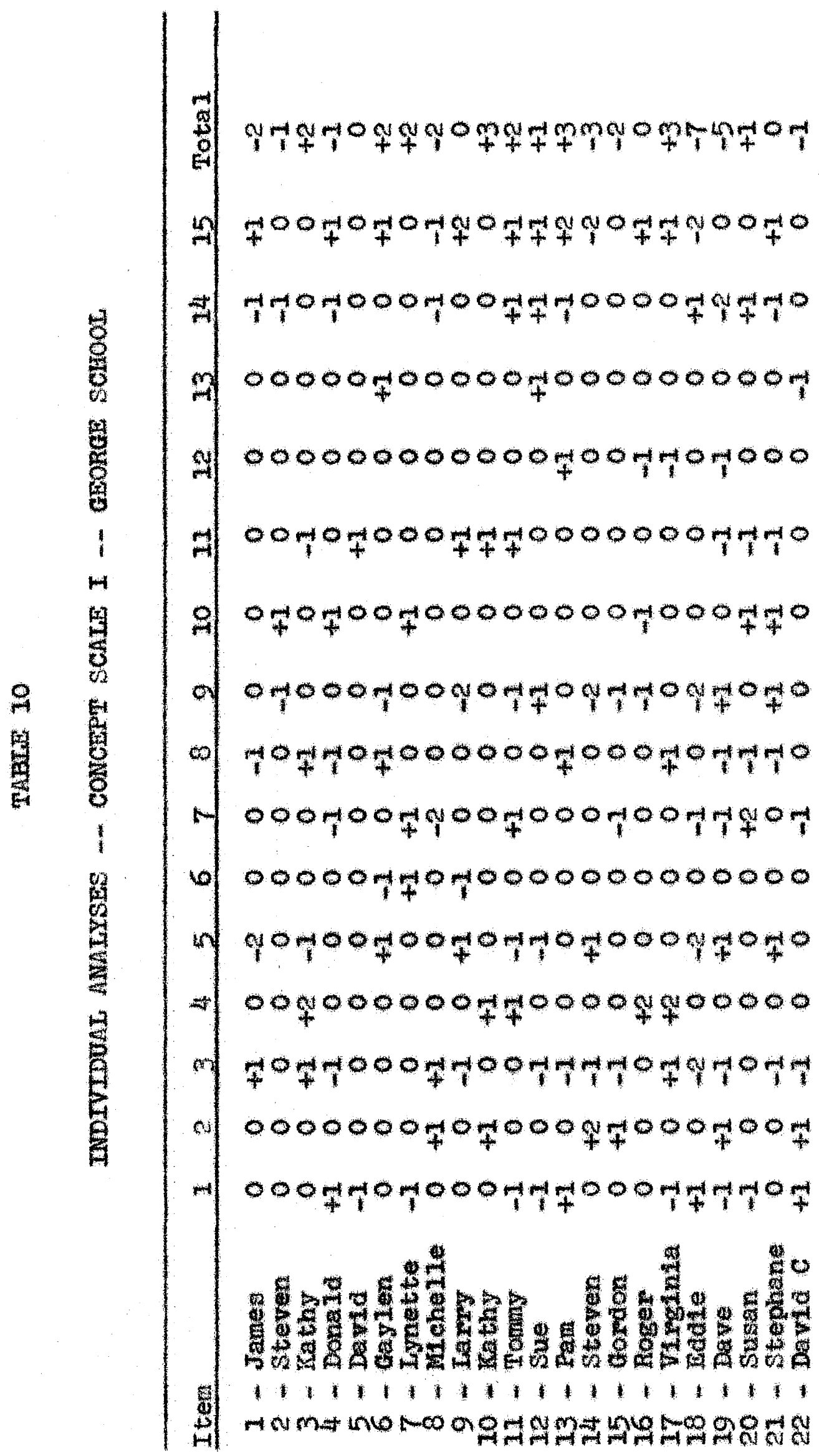




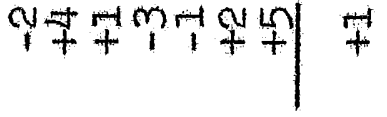

$$
\begin{aligned}
& \text { 40.7O+ } \\
& \text { Th4000 } \\
& \text { 파잉 } \\
& \text { Otomool } \\
& \text { } 1000007 / \\
& \text { 国 } 00000074 \\
& 040004+\infty \\
& 04000047 \\
& \text { 0.10\%001 if } \\
& \text { 70000\%0/ } \\
& 00 \text { y } 0000 \\
& 00000709 \\
& \text { 1070000/ } \\
& 0+0+04019 \\
& 0+40 \% 00+19
\end{aligned}
$$

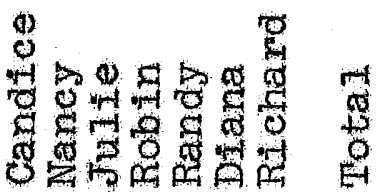

$$
\begin{aligned}
& 111111
\end{aligned}
$$

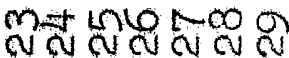




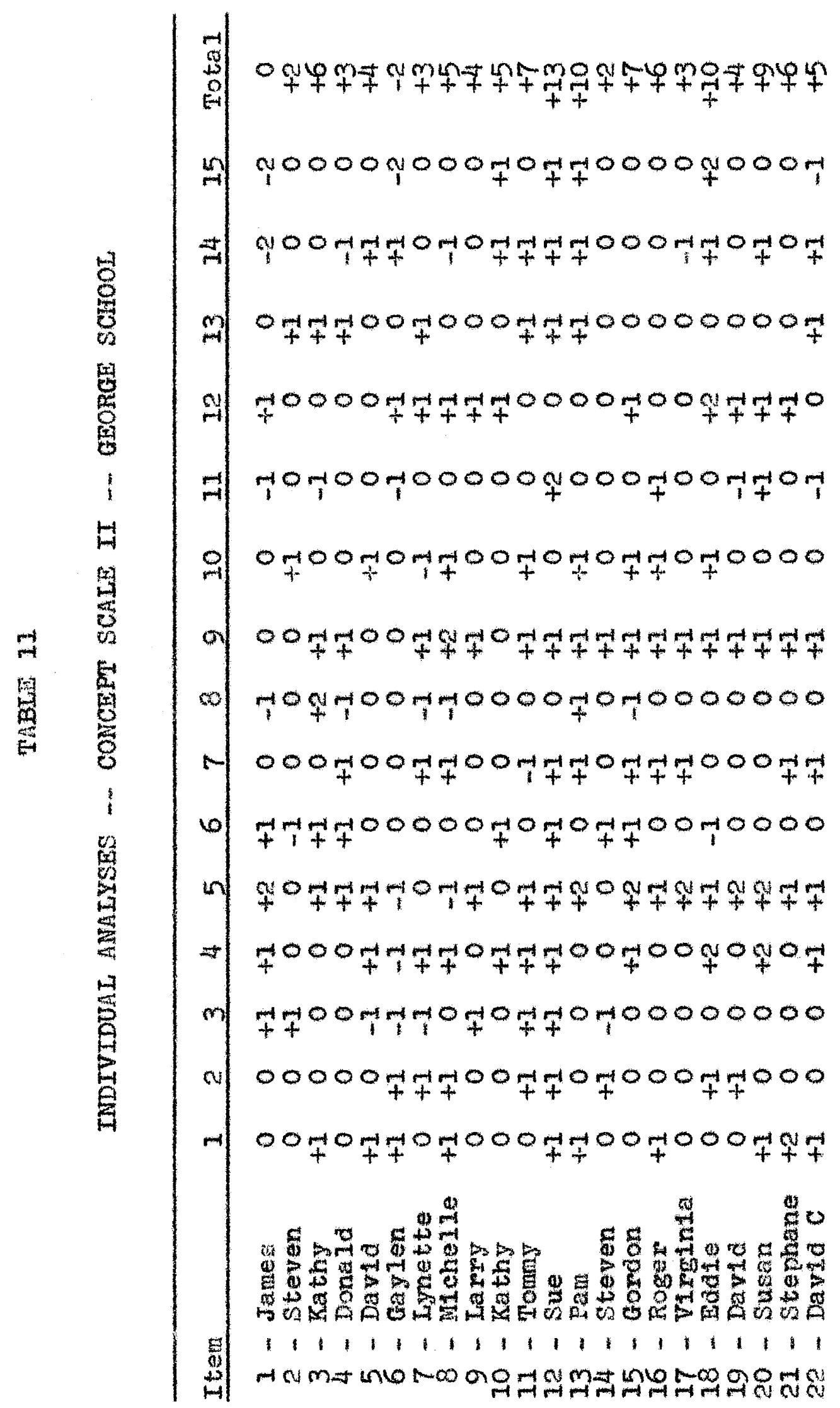




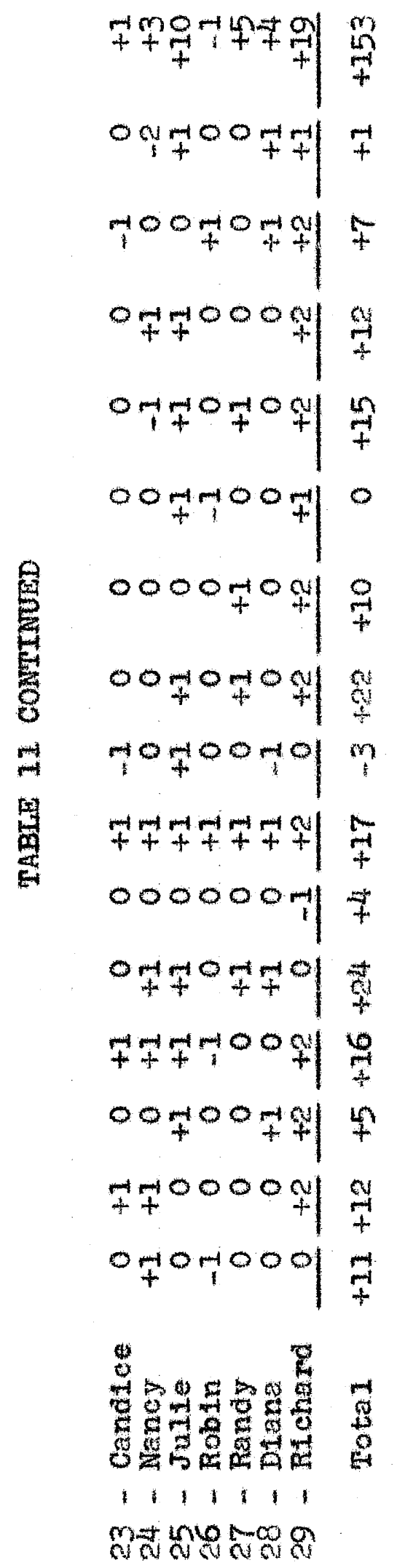




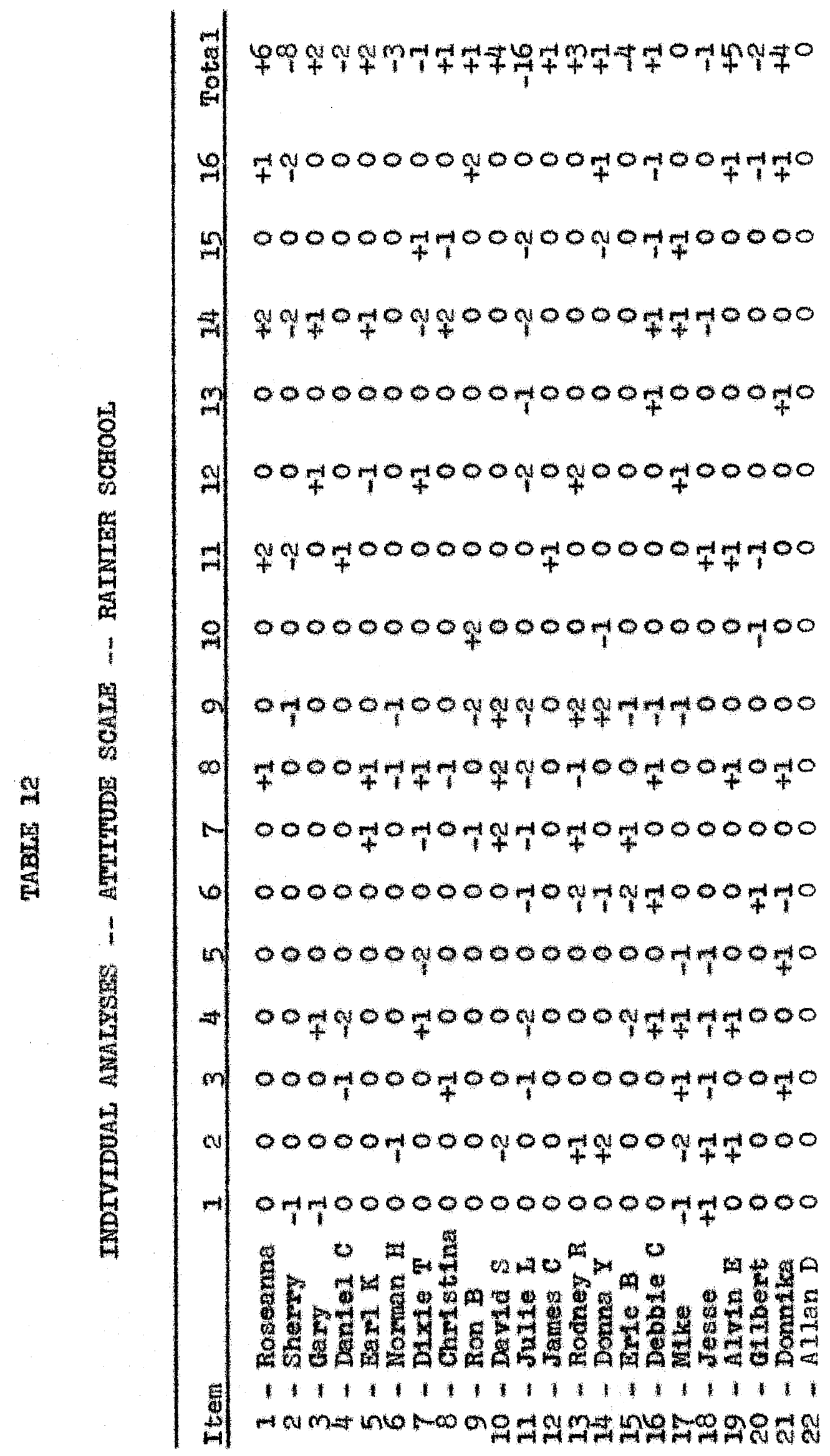




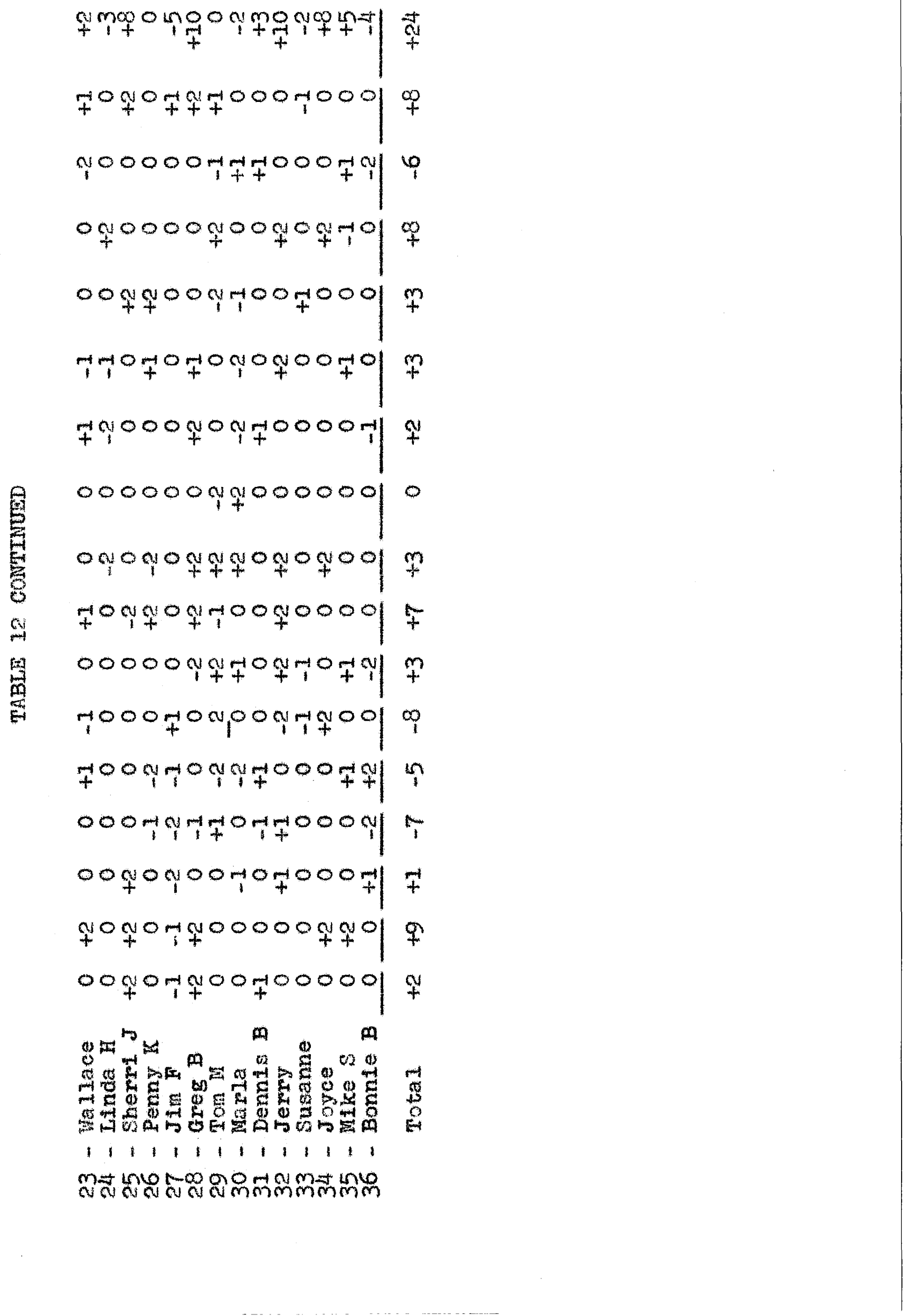




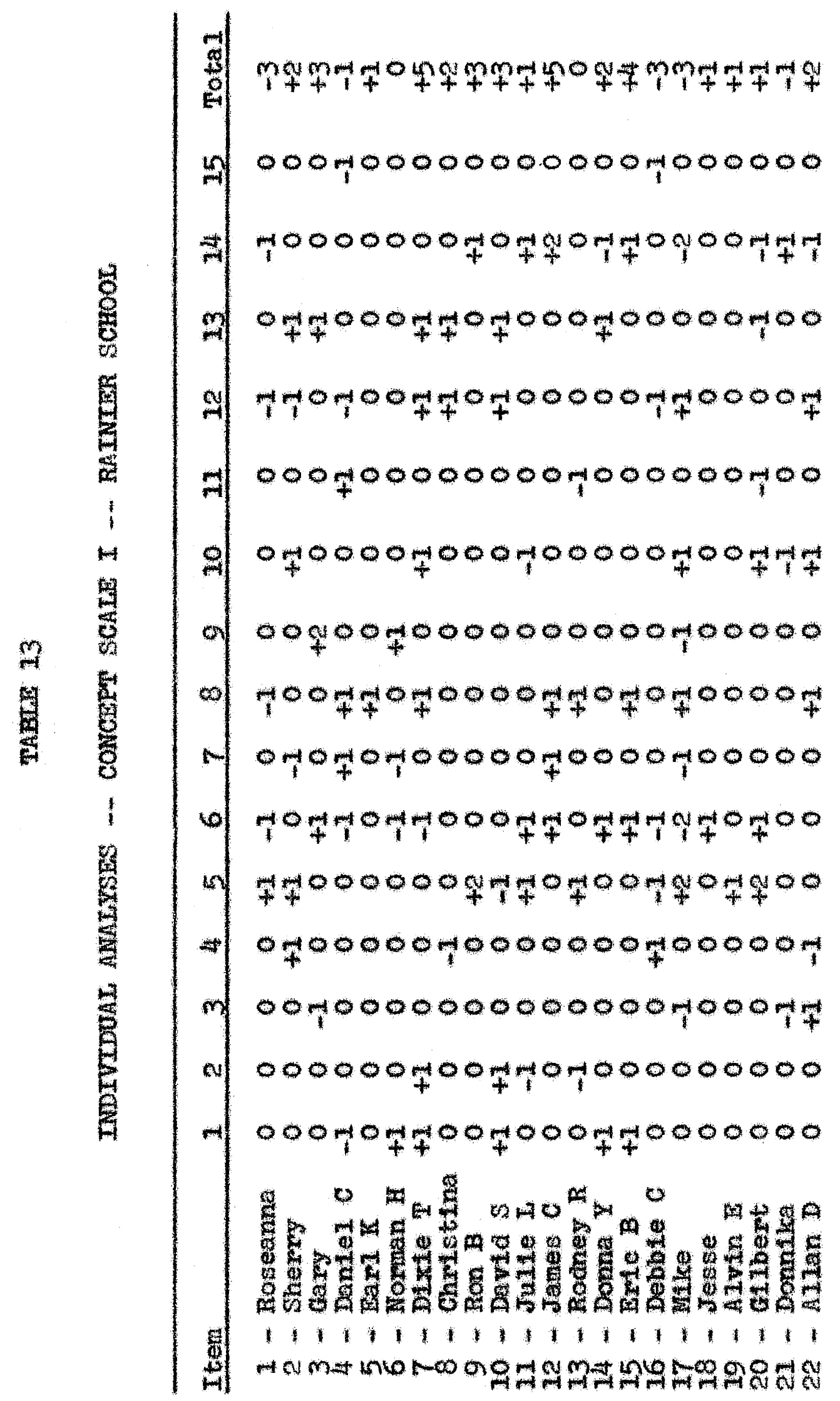




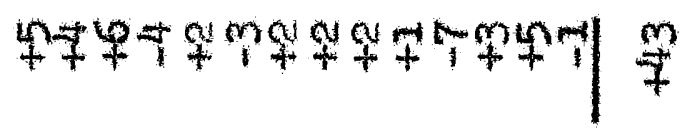

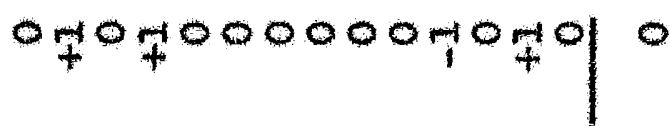

00 껀연

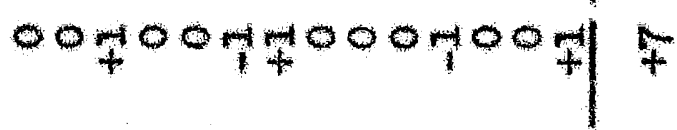

0 400000000000 स

T0700000000\%00| T

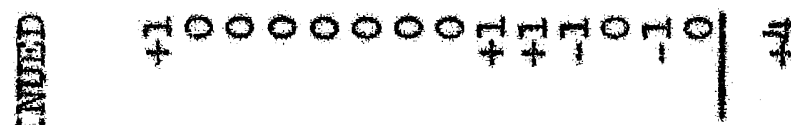

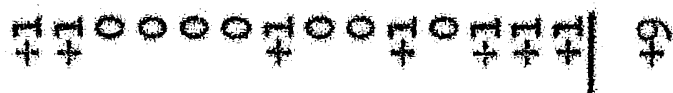

F40000000연이 9

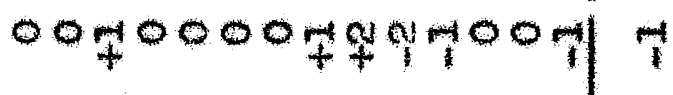

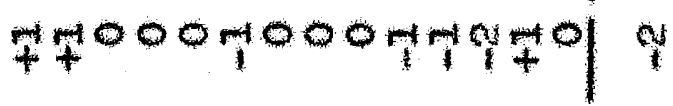

007007007000게

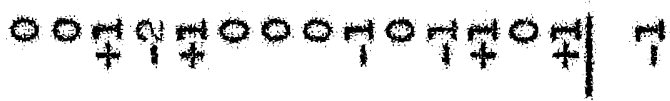

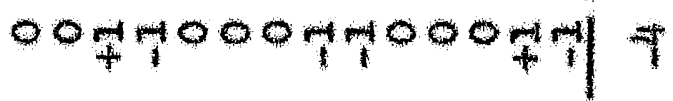

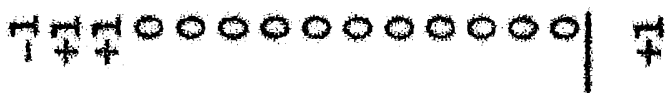

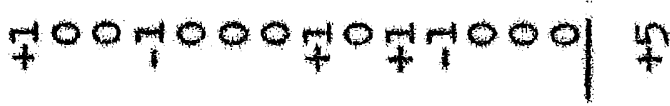

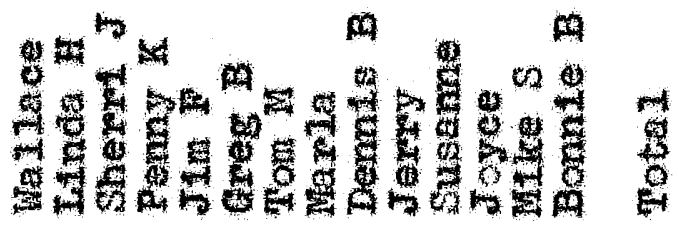

$111111+11111$

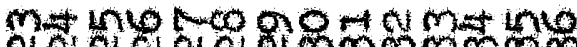

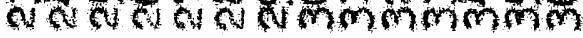




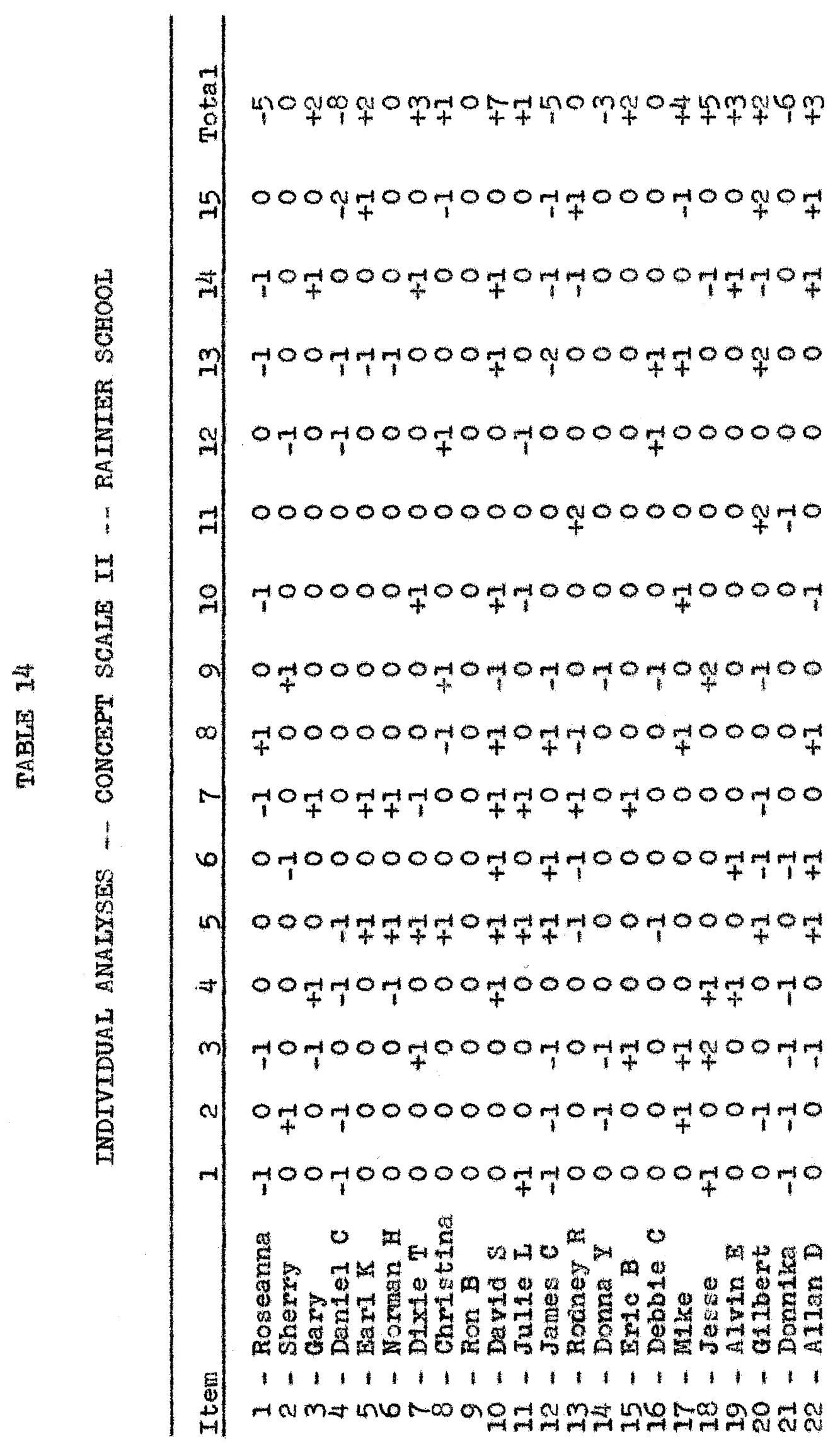


中+7\%q

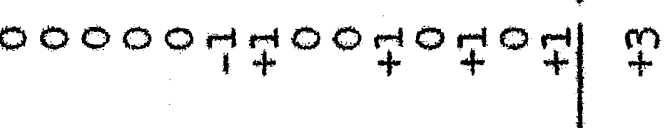

Om0m

fom tom

स०⿴囗十

$000 \% 000000700 \mathrm{l}$

507400000000\%010

000700040407074

47 $10000000707+114$

F0090000000\%

in

OHFHFO0000\%000 4

$7+00000707 \%+0 \pi 14$

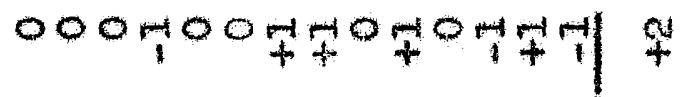

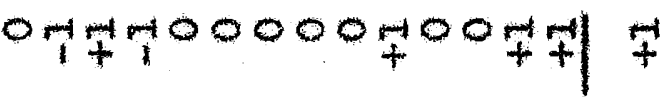

Fomf 7004000000017

00400040\%0004t m

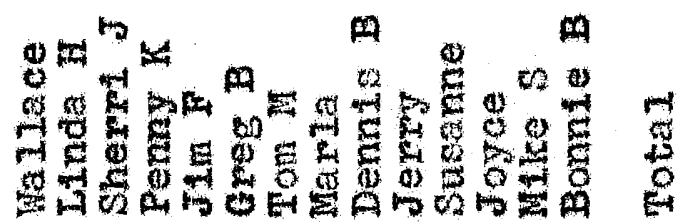

1111111111111

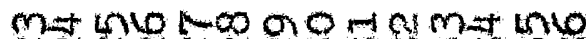

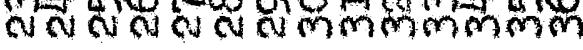




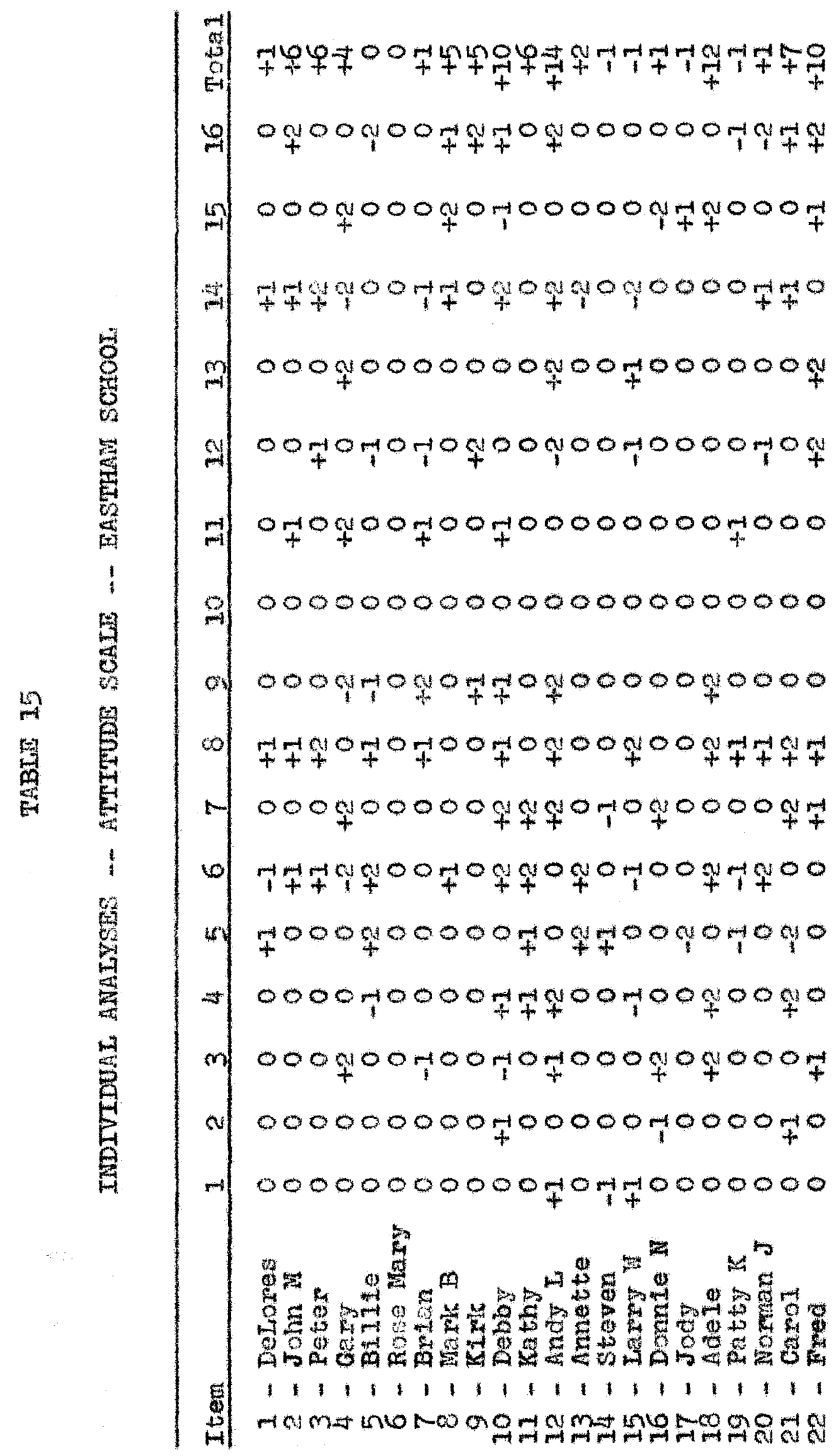




$$
\begin{aligned}
& \text { ofooogmmol } \\
& \text { oomoogoog } 9 \\
& 040000 y+74 \\
& 00000+4004 \\
& 00700000019 \\
& 0 \text { 4000700y t } \\
& 00000000+1 \\
& 000000000 \\
& 00000200015 \\
& \text { oqfaco00 } \frac{\text { m }}{4} \\
& \text { oyooomoool }
\end{aligned}
$$

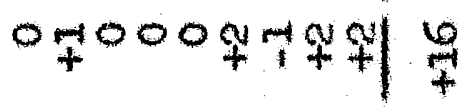

$$
\begin{aligned}
& 0+10000 \mathrm{ml} \\
& 0+000+0401
\end{aligned}
$$

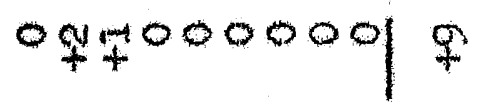

$$
\begin{aligned}
& 0 \text { 1000000.1 } \\
& 004000000
\end{aligned}
$$

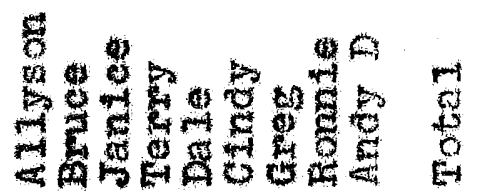

$$
\begin{aligned}
& 1111111
\end{aligned}
$$

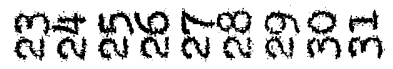




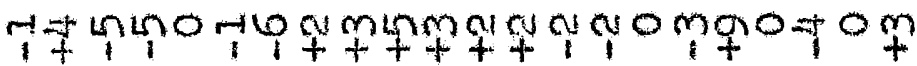

$00700 \% 000900000 \% 0$ f $000 \%$

$04000 \pi 00000400000+400$

$0000000400+400+00 \% 00+0$

000 m0040004000म 1000700

$000 \% 0070000000000$ t

$000000 \% 000000 \% 00 \% 40000$

70000000 H0000

700 $1000 \% 00000470000+00$

5000000007000

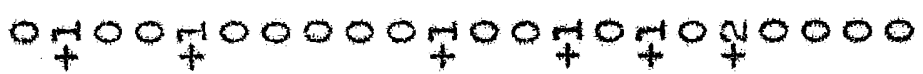

$040700400700404000 \% 000$

$0400009000000404+100000$

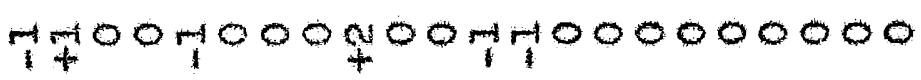

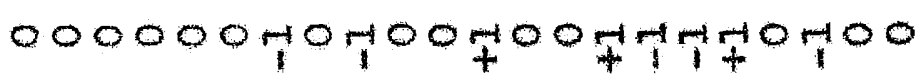

$04+400004004+4 m 0 m+0 m 00$ की

11111111111111,1111111 मलm- ज० 


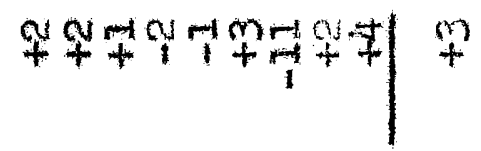

$$
\begin{aligned}
& 000000 \% 00 \mid 0 \\
& 0000004001 \\
& 000000 m+14 \\
& 000000 \% 001 \text { in } \\
& 00000404+ \\
& \text { moomonol } \\
& \text { 4opropasol } \\
& 0 \text { 1 } 000040017 \\
& \text { 000moontol t } \\
& 00 \text { figomol } \\
& 000000 \text { m } \\
& \text { toogotool } \\
& 000007004 \text { t } \\
& 000070000 \mathrm{~m} \\
& 000000000 \frac{m}{4}
\end{aligned}
$$

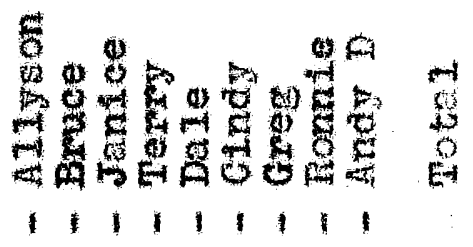

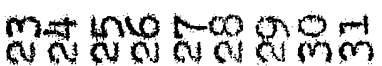




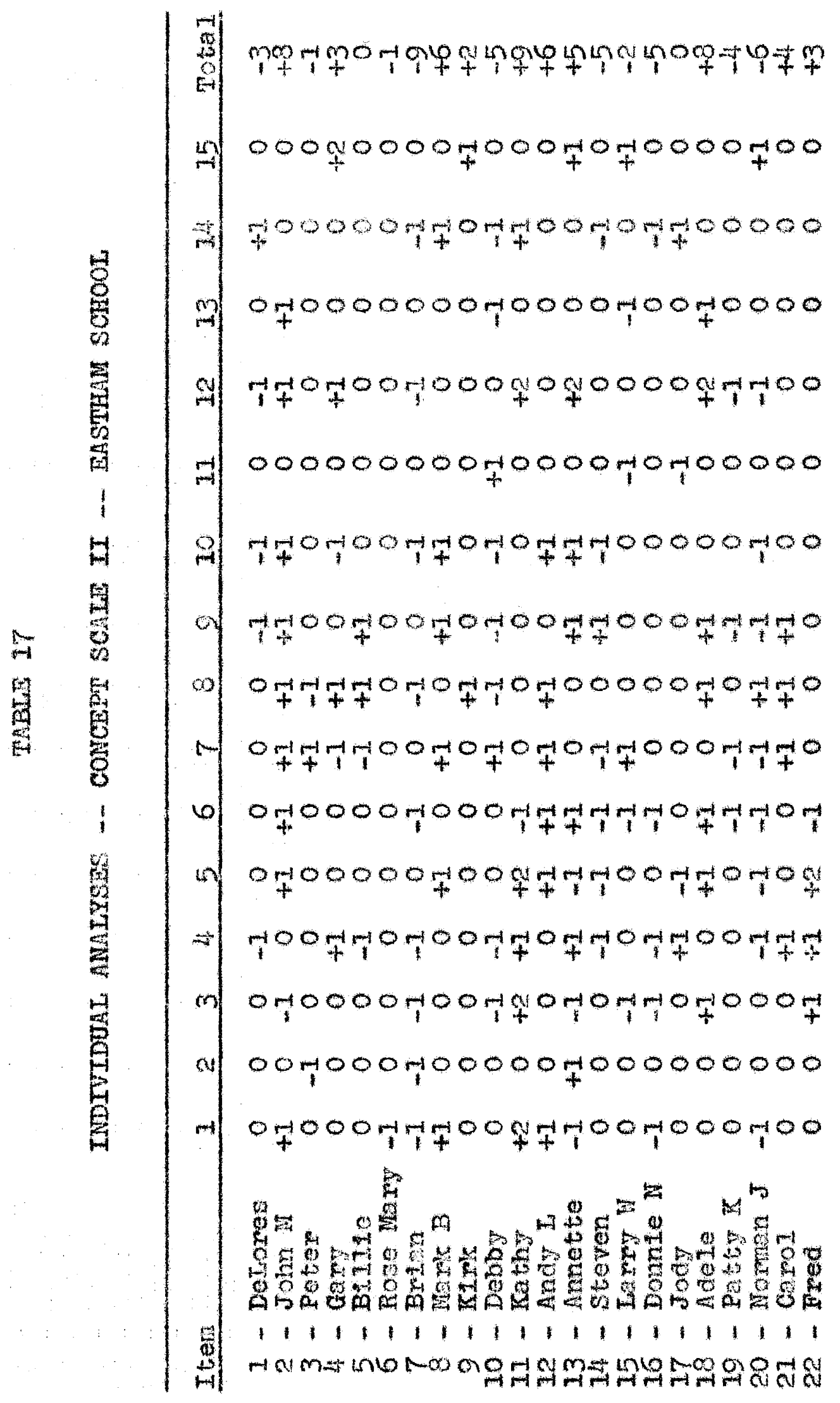




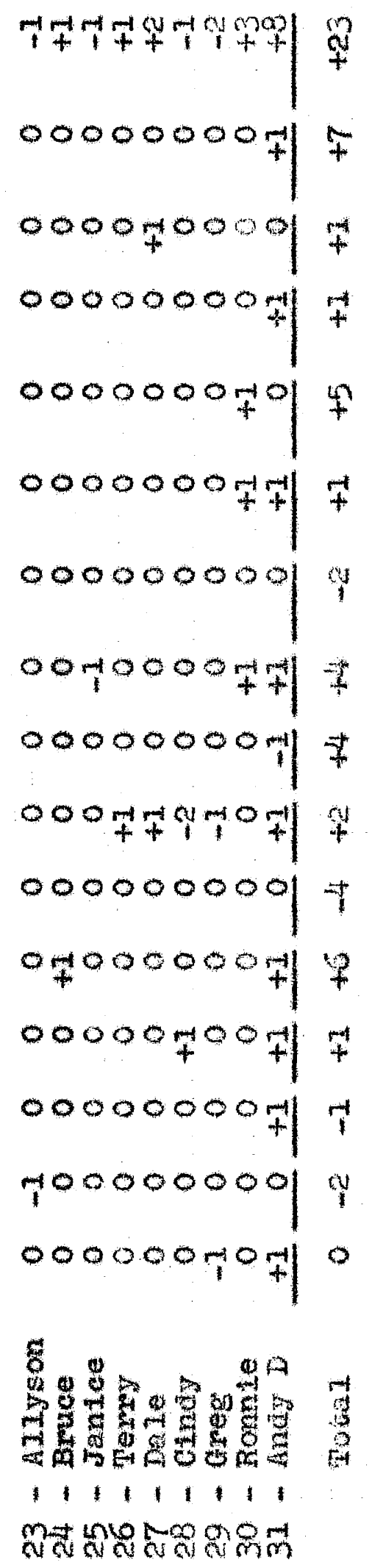




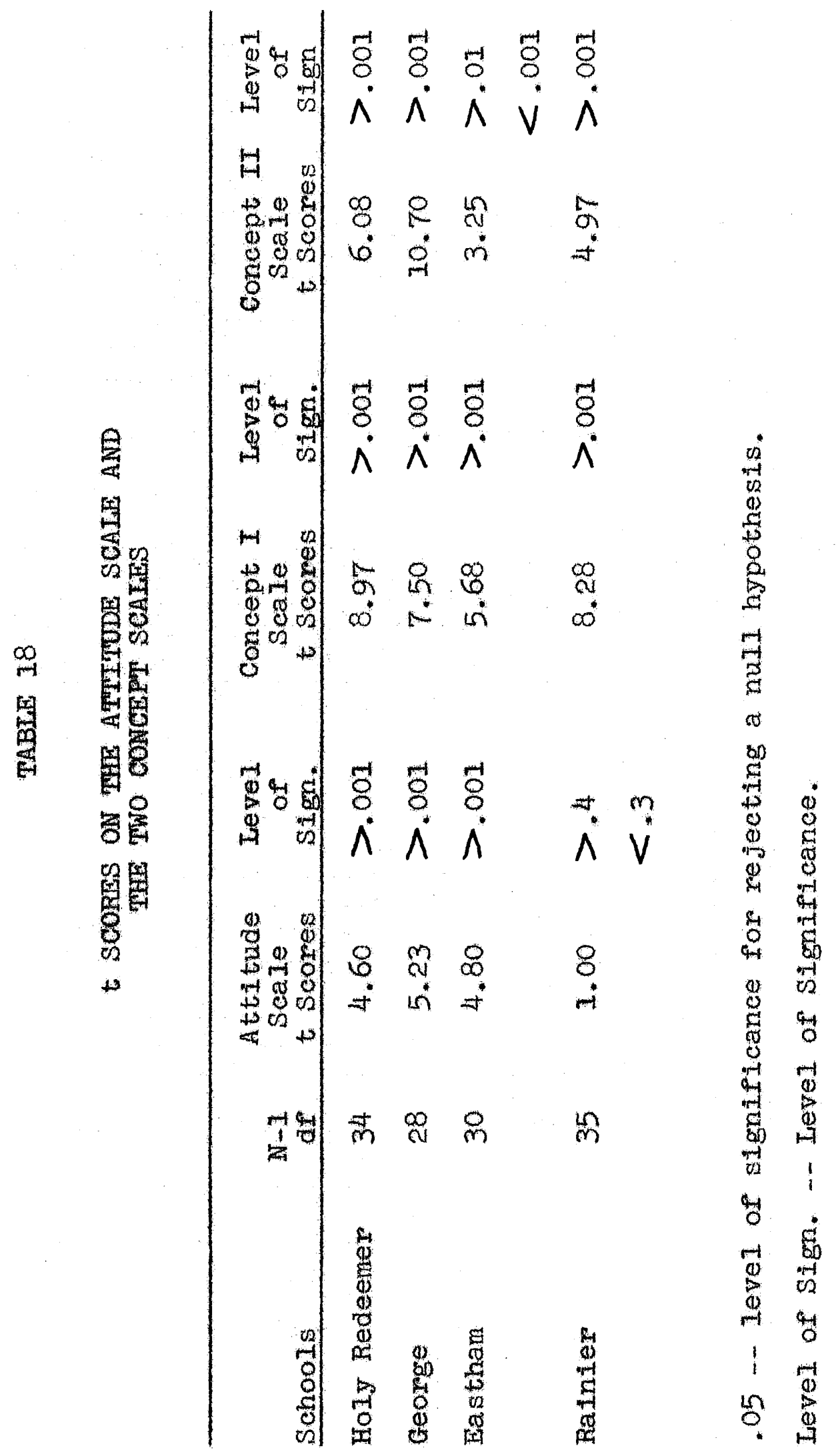


The diary

One week before the students, at Holy Redeemer School, attended the outdoor school they were each given a diary and asked to record their comments about the "things" they thought were interesting. They were also told that the diamles would be collected one week after they returned from the outdoor school. No attempt was made to remind the students of this responslbility or were they told how or when to make an entry.

Twenty, or forty-five percent, of the diarles were returned to the writer at the designated time.

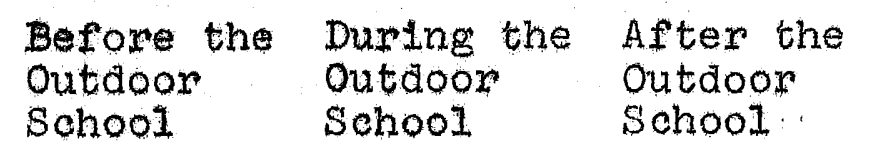

The number of students writing in their diaries, 20 16 5.

The number of words used by the group, 6,501 2,393 541.

The number of words used by the group that pertained to the school or a school activity, $3,182 \quad 2,128.248$.

A word analysis was made in an attempt to record any pattems or frequencles concerning students' values. Table 19 111ustrates the frequency of the unabridged values mentioned by the students. 
FREQUENCY DISTRIBUTION OF VALUES MENTIONED BY STUDENTS ONE WEEK BEFORE THE OUTDOOR SCHOOI, EXPERIENCE, DURING THE WEEK OF SCHOOL, AND ONE WEEK AFTER THE SCHOOL

\begin{tabular}{|c|c|c|c|}
\hline \multirow[b]{2}{*}{ Values } & \multicolumn{3}{|c|}{ Times Mentioned } \\
\hline & Before & During & After \\
\hline Campfire is very good & & 1 & \\
\hline DIdn't like "plant teacher" & 1 & $\vec{I}$ & \\
\hline Don't like camp - schoo1 & $\bar{I}$ & $\bar{I}$ & \\
\hline Excited about going to the & & & \\
\hline $\begin{array}{l}\text { outdoor school } \\
\text { Enfoyed the teachers or counselors }\end{array}$ & 8 & $\frac{1}{11}$ & \\
\hline $\begin{array}{l}\text { Enjoyed the teachers or counselors } \\
\text { Fun school }\end{array}$ & & & \\
\hline $\begin{array}{l}\text { Fun school } \\
\text { Fun to do things }\end{array}$ & 1 & $\begin{array}{l}5 \\
3\end{array}$ & \\
\hline Fun getting peady for the school & 4 & & \\
\hline Feeling mighty low & 1 & & \\
\hline $\begin{array}{l}\text { Food is good } \\
\text { Field studes are fun }\end{array}$ & & $\begin{array}{l}2 \\
7\end{array}$ & \\
\hline $\begin{array}{l}\text { Glad to get out of school } \\
\text { Got in trouble (in class) }\end{array}$ & $\frac{1}{3}$ & & \\
\hline $\begin{array}{l}\text { Helping others is fun } \\
\text { Keen gehool }\end{array}$ & & 1 & \\
\hline $\begin{array}{l}\text { Iea med a lot } \\
\text { Looking forward to meet }\end{array}$ & & 1 & \\
\hline $\begin{array}{l}\text { Lookfing forward to meet } \\
\text { wonderful people }\end{array}$ & 1 & & \\
\hline N1ssed home & & 1 & \\
\hline Made new friends & & 1 & \\
\hline Not fun being a hostess & & 1 & \\
\hline Nothing much today & 1 & & 4 \\
\hline $\begin{array}{l}\text { Pretty good sohool } \\
\text { Plant atudy is boring } \\
\text { Real nice }\end{array}$ & & $\begin{array}{l}\frac{2}{1} \\
\frac{1}{1}\end{array}$ & \\
\hline Real happy place & 1 & 1 & \\
\hline $\begin{array}{l}\text { Surprised that teachers could } \\
\text { Jaugh }\end{array}$ & & & \\
\hline $\begin{array}{l}\text { Laugh } \\
\text { Sorta 11ke sohool }\end{array}$ & & 1 & 1 \\
\hline Satisfied with myself & & 1 & \\
\hline Sad to leave the school & & 1 & \\
\hline Thankful for the wonderful & & & \\
\hline teacher & & 1 & \\
\hline $\begin{array}{l}\text { Water study was fun } \\
\text { Wlidife study was best }\end{array}$ & & $\frac{1}{2}$ & \\
\hline Wonderful experience & & 1 & \\
\hline We are lucky kids & & 1 & \\
\hline
\end{tabular}


CHAPTER VI

SUMMARY, CONCIUSIONS, AND RECOMNENDATIONS

This study constitutes an attempt to explare and measure att1tudes prior and subsequent to an outdoor school program. The study was an 1nvestigation of the attitudes of students toward the natural environment, what the student thought of hlmsele, and what the student thought otherg thought of $\mathrm{h} 1 \mathrm{~m}$.

Data was secured from 131 sixth grade boys and girls ranglng from lower to high soc10-economic backgrounds. The test group spent $1 \mathrm{x}$ days at an outdoor school, located in Colton, Oregon.

The gtudy concemed 1tself with investigation of the following hypotheses:

1. Students' experiences at the outdoor school will not signiflcantly change the 1 attitude tower the naturat enviromment.

2. The experience attributed to the outdoor school w111 not signifleantly change the student's view of himself.

3. The self-concept of the student as he thinks others view him will not be slgnifleantly changed by the outdoor experience.

Instmuments of appralsal used to meagure and evaluate the response of the test group were:

1. A sixteen item Att1tude Scale towand the natural environment. 
2. Concept Scale I, indicating how the student thinks of himself which contained fifteen items.

3. Concept scale II, Indicating how the student thinks others view him, which also contained fifteen items.

4. A Dlary that one group kept their comments in one weak before the outdoor school, the weak during the school, and one week after their return.

The design of the study included testing all the students before and after the outdoor experience by means of the three scales. An analysis of the students diaries was made to record any values that may have been mentioned. A stat1stical measure of reliability was calculated on each of the three scales,

\section{Summary of eindings}

The findings presented here were gained through analysis of the data from the students' responses to questions contained on the survey scales. The $t$ score statistical technique was applied to each group representing the four schools to determine if there wa a significant difference In mean responses, Table 18.

This study revealed that the experience of the outdoor school did significantly change the attitude of the test group in respect to their attitude towaxd the natural environment. The group from George School exhibited an 
attitude change signiflicant beyond the .001 level. The group from Holy Redeemer and Eastham also displayed a level of change greater than .001 significance, thereby the groups rejected the null hypothesis. For the Ralnier group the null hypothesis was accepted. The discrepancy In these results cannot be accounted for by the investigator, Table 12. Visual examination of this same table reveals an extreme negative move of one student which would influence group performance, Further analysis show that one-half of this group moved in a negative direction or had no change in attitude after the outdoor experience.

The experiences attributed to the outdoor school significantly changed the self-concept of the test group in a pog1tive way. The change in, "How the student viewed himself," proved to be significant well beyond the .001 level of signiflcance thus the null hypothesis is rejected. All the participating groups ranked beyond the .001 level of significance. It is interesting to note that the $t$ score values obtained from these scales are closely in agreement. With the exception of the test group from Eastham a hlgh degree of agreement may also be observed with respect to the $t$ score values representing the concept, "How the student thinks others view hIm." In each case the null hypothesis was rejected, Table 18 . 
Of lesser significance to the evaluation of the findings is the analysis of the diaries. Although a sufficient number were retumed, and the initial enthusiasm seemed encouraging, it soon became apparent that this loosely structured method of soliciting comments from students did not produce the deaired outcomes. The tendenoy for students to respond to something "new" may be responsible for their Intitial concern and excitement. See page 79 and Table 19. Conclustions

Judging from the results of this study, the following conclustions seemed justifled:

1. The expertienoe of the outdoor school provides situations that affect childrens' attitudes toward the natural environment in a positive way.

2. The outdoor school Increages the value of relationships that is conducive to the attalnment of a favorable self-concept.

3. The effect of the outdoor school pertaining to specific attitudes and self-concepts of the test groups proved to be measurable by the scales which were constructed.

Recommendations

1. Additional studies should be carried out to determine the value of soclometric information 
In identifying desirable and productive attitudes.

2. Ways and means of investigeting childrens'

individual self-concepta and attitudes over long pexiods of time should be explorea.

3. Outdoor school programs should be further investlgated to detemine the unique contributions to younger boys and girls.

Much more investigation is needed in all aspects of outdoor education in oregon. Hopefuliy, others w111 undertake the task of ferreting out additional information that w11 enlighten educators to the implications offered by outdoor schools. Even on a theoretical level outdoor experiences may be able to start in some children a process of change both in attitudes toward himself and toward the environment in which he lives. 


\section{BIBIIOGRA PHY}

\section{Books}

1. Bernstein, Allen I. A Handbook of Statistical Solutions for the Behavioral seIences. HoIt-Rinehart and Winston, Inc. 1964.

1a. Combs, Arthur W. "A Perceptual V1ew of the Adequate Personality." Percelving, Behaving, Becoming. ASCD Yearbook, 1201 Sixteenth St., N.W., washington, D.C. , 1962.

2. Hammerman, William and Donald. Teachlng in the outdoons. Burgess Publishing Co, Minneapolis, Minnesota, 1964.

3. Irwin, Frank I. The Theory of Camping. A.S. Bames and Company. New York, 1950.

4. Kolb, Haven and Assoclates. High School Blology-BSCS Green Version. Rand McNaliy and Company, Chicago, IIIInoIs, 1963.

5. Manley, Helen and Drury, M.F. Education Through School Camping. C. V. Mosby Company, St. Louls, 1952.

6. Maslow, Abraham H. Toward a Psychology of Belng. D. Van Nostrand Company, Inc. Princeton, New Jersey. 1962

7. Sears, Pauline S. and Sherman, Vivian S. In Pursuit of Self-Esteem. Wadsworth Publishing Company, Belmont, Callfornia, 1966.

8. Smith, Carlson, Donaldson and Masters, Outdoor Education. Englewood Cliffs, New Jersey, Prentice-Hall, 1963.

9. Sullivan, H. S. The Meaning of Anxiety in Poychiatry and In Iffe. Wilitam Alanson White Institute of Psychlatry, New York, 1948.

9a. Wert, James E., and Assoclates. Statistical Methods in Education and Psychological Research. Appleton-CenturyCrofts, Inc, New York, 1954.

10. Wy1le, Ruth. The Self-Concept, A Critical Survey of Pertinent Research. IIncoln, UnIversity of Nebraska Press, 1961. 
Unpublished Doctoral Dissertations

11. Davidson, Morris. Changes in Se1f-Concepts and Soclometric Status of Fifth and Slxth Grade Children as a Result of Two DIf ferent School Camp Curricula. University of california, 1965.

12. Johnson, Tessa Mae. An Evaluation of a Semi-Objective Method for Appraising Selected Educational outcomes of School Camplng. University of Southem Callfom1a, Los Angeles, 1957.

13. Kranzer, Charles H. Effects of School Camping on Selected Aspects of Pupli Behavi or-An Experimental Study. University of Calt Poria, Los Angeles, 1958.

14. Stack, Genevie, An Evaluation of Attitudinal Outcomes of F1fth and Sixth crade Students Following a Period of School CampIng. UnIversity or OKlahoma, I960.

Periodicals and Pamphlets

15. Brandwe1n, Paul. "Conservation", The Sclence Teacher. Volume 34, Number 4, Apri1, 1967.

16. Ch1ldhood Education., Volume 44, Number 2. Assoclation For ChI dhood Education Intemational, Washington, D.C. 1967.

17. Ghildren's Vlews of Themselves. Association for ChIldhood Education International. 3615 Wisconsin Avenue, Northwest, Washington, D.C., 1959.

18. Coppersmith, Stanley. "Studies in Self-Esteem." Scientific America. Volume 218, Number 2, February 1968.

19. Criteria For Evaluation of Catholic Elementary Schools. Holy Redeemer School, 127 North Portiand BIvd, Portiand, Oregon. May 19, 1967.

20. Foshay, Arthur W, and Assoctates. Ch1ldren's Social Values. New York Bureau of Publications, Teacher's College, Columbia UnIversity, 1954.

21. GIIbert, H, B. and Wrightstone, J. W. "Education's New Look: Camping," School Executive. 67:31-4, June, 194.8. 
22. Grumprecht, Helmuth, "Common Emotional Disturbances of Children at Camp." Nervous Child. Volume 6, Number 2, Apri1, 1947.

23. Harms, Emest. "Camping for What?" Nervous Child. Volume 3, Number 3, Apr11, 1944.

24. Joumal of Outdoor Education. Volume 2, Number 2 IIIInoIs University, DeKaIb, IIlinois, 1968.

25. Lewin, Herbert $S$. "Changes of Attitude Subsequent to Camp Experience." Nervous Child. Volume 6, Number 2, Apri1, 1947.

26. Iife Camps Inc. "Basic Issues in Camping and Outdoor Education." Extending Education, 111:1-8 November, 1946.

27. Means, Richard I. "Why Worry About Nature?" Saturday Rev1ew. December 2, 1967.

28. Outdoor Education in Oregon Schools. State Department of Education, Salem, Oregon, $\frac{1968 .}{19}$

29. Proposal For Operation Grant, Title III, Regiona1 outdoor Program, P. O. Box 917,, Portiand, Oregon, 1965.

30. Providing Enrichment Opportunities Through Camping and other S1milax Aetivities-Elementary Program Evaluation. M1lwaukee Public Schools, Miliwaukee, Wisconsin. September 6, 1966 - June 16, 1967.

31. Rademacher, Everett. "The ChIla's Readiness for Camp." Nervous Child. Volume 6, Number 2, Apri1, 1947.

32. Red1, F. "Psychopathologic Risks of Camping." Nervous Child. Volume 6, Number 2, Apri1, 1947.

33. Sharp, Lloyd B. "Basie Considerations in Outdoor and Camping Education." National Association of Secondary School Principals. The Bulletin. Volume 147, May 1947.

34. The Teacher's Handbook For the Outdoor School. Regional outdoor School. 1441 S. E. 122nd Ave. Portland, Oregon, 1965. 
APPENDIX A

\section{INITIAI STUDENT SURVEY SHEET}

Suppose you were asked to talk about yourself. Would you please make a list of the words that you would use. 


\section{APPENDIX B}

\section{INITIAL STUDENI WORD LIST SURVEY}

One-hundred and elght sixth grade boys and girls were asked to respond to the questlon: "What word or group of words would you use if someone were to ask you to talk about yourself?" The frequency that each word occurred is included in parenthesis.

adventurous
always in trouble
afrald
aggressive ( 2$)$
active (2)
bossy (2)
bold
brilijant
brat
beautiful (2)
bad (4)

confident

clever $\operatorname{cool}(7)$ crazy (2) coordinated (3) critical cute $(7)$ cheerful clean $(7)$ clumsy (2) courteous $(4)$ cheat competitive $(3)$ concelted (2) curlous cooperative (2)

different (2) dumb (3) don't like to work like to do things extra ordinaxy famous

fantastic

faithful

frtendly (11)

funny (3)

fun $(2)$

fun to be with

frustrated easily

gay

generous

goofy (2)

groovey (9)

great (7)

good (6)

good worker

get along (2)

good looking

get work done

humorous (e)

hippish

helpful (2)

happy $(3)$

hate school

Inte11igent ( 14)

Imaginative

important

interesting (2)

1 ikeable (2)

mighty

mean

mad $(e)$

make friends easily

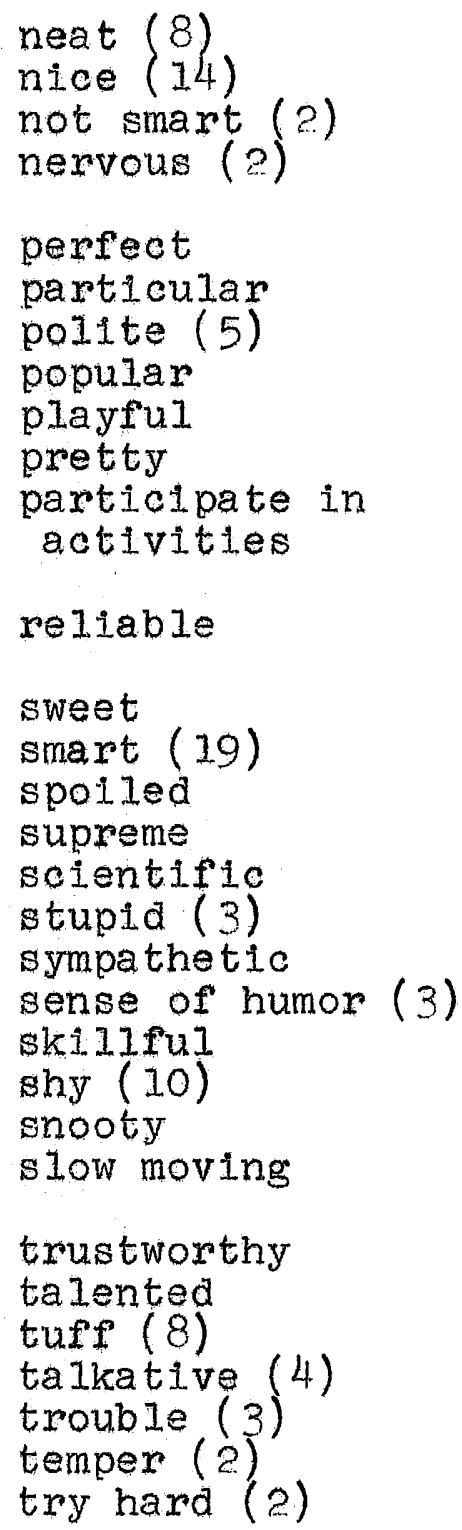


wishy-washy

wonderful

weak

witty (e)

we 11 organized

queer

us $1 \mathrm{y}$ (3)

quiet (3)

unkind (2)

kind (6)

unliked 


\section{APPENDIX C}

\section{INITIAI STUDENT IIST}

Dear student,

Read each word or phrase carefully. Put a mark ( ) by each word that you think you would use when talking about yourself. Remember, only mark the words you would use in talking about yourself.

Thank you.

80 active

17 aggressive

18 afraid

9 a Iways in trouble

17 bossy

9 beautiful

5 bad

16 bold

270001

2द cute

50 courteous

82 clean

14 compet 1 tive

2 cooperative

21 concelted

21 clumsy

24 confident

33 alferent

12 dumb

12 don't like to try new things

78 friendly

37 funny

23 frustrated eas $11 y$

41 fun to be with

21 groovey

17 great

53 good

13 goofy

68 get along

40 gay

74 happy

65 helpful

33 humorous

40 intelingent
20 Important

22 interesting

59 likeable

9 mad

57 make frlends easily

$6 \overline{2} \mathrm{nice}$

55 nest

17 not smart

26 nervous

66 polite

19 popular

58 participate in new activities

40 rellable

40 smart

13 spolled

33 shy

10 stupid

19 sympathetic

2I tough (tuff)

Itrouble

63 try hard

54 ta $1 \mathrm{~kat}$ ive

59 trustworthy

29 temper

9 witty

15 ug $1 y$

26 quiet

6 unkind

$33 k$ ind

$1 \overline{1}$ unliked

32 well organized

9 wishy-washy

0 snooty

$4 \overline{7}$ ski11ful 


\section{APPENDIX D}

\section{CONCEPT SCALE I}

Dear student,

A11 you have to do is read each statement and put a mark ( ) in the column to show the way you feel. Mark the statements quickly because there are no right or wrong answers.

Thank you for your help.

\begin{tabular}{|c|c|c|c|}
\hline & $\begin{array}{l}\text { This is } \\
\text { very much } \\
\text { like me }\end{array}$ & $\begin{array}{l}\text { A } 1 i t t i e \\
\text { bit } 11 k e \\
\text { me }\end{array}$ & $\begin{array}{l}\text { Not 11ke } \\
\text { me at } \\
\text { a11 }\end{array}$ \\
\hline $\begin{array}{l}\text { 1. I have self- } \\
\text { control. }\end{array}$ & & & \\
\hline $\begin{array}{l}\text { 2. I am trust- } \\
\text { worthy. }\end{array}$ & & & \\
\hline $\begin{array}{l}\text { 3. I am afraid of } \\
\text { many things. }\end{array}$ & & & \\
\hline $\begin{array}{l}\text { 4. I am awkwara } \\
\text { and cIumsy. }\end{array}$ & & & \\
\hline $\begin{array}{l}\text { 5. I am confident, } \\
\text { not shy or timid. }\end{array}$ & & & \\
\hline $\begin{array}{l}\text { 6. I often feel } \\
\text { left out of } \\
\text { things }\end{array}$ & & & \\
\hline $\begin{array}{l}\text { 7. There is not } \\
\text { much use for me } \\
\text { to try hard. }\end{array}$ & & & \\
\hline $\begin{array}{l}\text { 8. I am fun to be } \\
\text { with. }\end{array}$ & & & \\
\hline 9. I am a Ieader. & & & \\
\hline
\end{tabular}




\begin{tabular}{|c|c|c|c|c|}
\hline & & $\begin{array}{l}\text { This is } \\
\text { very much } \\
1 \text { lke ne }\end{array}$ & 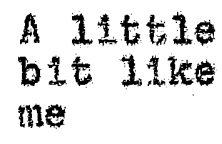 & $\begin{array}{l}\text { Not } 11 \mathrm{ke} \\
\text { me at } \\
\text { a } 11\end{array}$ \\
\hline \multicolumn{5}{|c|}{$\begin{array}{l}\text { 10. I make Priende } \\
\text { eas 11y. }\end{array}$} \\
\hline \multicolumn{5}{|c|}{$\begin{array}{l}\text { 11. I can solve } \\
\text { problems by } \\
\text { nyself }\end{array}$} \\
\hline \multicolumn{5}{|c|}{$\begin{array}{l}\text { 12. I have a good } \\
\text { sense of humox. }\end{array}$} \\
\hline \multicolumn{5}{|c|}{$\begin{array}{l}\text { 13. My decistone } \\
\text { are usua11y } \\
\text { mght. }\end{array}$} \\
\hline \multicolumn{5}{|c|}{$\begin{array}{l}\text { 14. I juat cannot } \\
\text { face fallure. }\end{array}$} \\
\hline 15. & $\begin{array}{l}\text { I am an } \\
\text { Important } \\
\text { peroon in my } \\
\text { clacsroon. }\end{array}$ & & & \\
\hline
\end{tabular}




\section{APPENDIX E \\ CONCEPT SCAIE II}

Dear Student,

A11 you have to do Is to read each statement and put a mark ( ) in a column to show the way you feel. Mark the statements quickly because there are no right or wrong answers.

Thank you for your help.

\begin{tabular}{|c|c|c|c|}
\hline & $\begin{array}{l}\text { Most of } \\
\text { the time }\end{array}$ & $\begin{array}{l}\text { Some of } \\
\text { the tIme }\end{array}$ & Seldom \\
\hline $\begin{array}{l}\text { 1. People think of } \\
\text { me as being } \\
\text { Important. }\end{array}$ & & & \\
\hline $\begin{array}{l}\text { 2. My classmates } \\
\text { trust me. }\end{array}$ & & & \\
\hline $\begin{array}{l}\text { 3. Most people } \\
\text { Iike me. } \\
\end{array}$ & & & \\
\hline $\begin{array}{l}\text { 4. My elassmates } \\
\text { have confidence } \\
\text { in me. }\end{array}$ & & & \\
\hline $\begin{array}{l}\text { 5. People respect } \\
\text { me. }\end{array}$ & & & \\
\hline $\begin{array}{l}\text { 6. My teacher } \\
\text { understands me }\end{array}$ & & & \\
\hline $\begin{array}{l}\text { 7. People think } \\
\text { that I am } \\
\text { helpful. }\end{array}$ & & & \\
\hline $\begin{array}{l}\text { 8. My teacher } \\
\text { thinks that I } \\
\text { try hard. } \\
\end{array}$ & & & \\
\hline $\begin{array}{l}\text { 9. My classmates } \\
\text { think I am } \\
\text { polite. }\end{array}$ & & & \\
\hline
\end{tabular}




\begin{tabular}{|c|c|c|c|c|}
\hline & & $\begin{array}{l}\text { Most of } \\
\text { the time }\end{array}$ & $\begin{array}{l}\text { Some of } \\
\text { the time }\end{array}$ & Seldom \\
\hline \multicolumn{5}{|c|}{$\begin{array}{l}\text { 10. Other chilaren } \\
\text { my age enjoy } \\
\text { being with me. }\end{array}$} \\
\hline 11. & $\begin{array}{l}\text { Classmates } \\
\text { make fun of } \\
\text { me. }\end{array}$ & & & \\
\hline \multicolumn{5}{|c|}{$\begin{array}{l}\text { 12. Other chlidren } \\
\text { my age think } \\
\text { I'm reliable. }\end{array}$} \\
\hline \multicolumn{5}{|c|}{$\begin{array}{l}\text { 13. Classmates think } \\
\text { I am friendly. }\end{array}$} \\
\hline 14. & $\begin{array}{l}\text { Other students } \\
\text { think I am } \\
\text { Priendly. }\end{array}$ & & & . \\
\hline 15. & $\begin{array}{l}\text { Most people } \\
\text { wish that I } \\
\text { were different. }\end{array}$ & & & $\because$ \\
\hline
\end{tabular}


APPENDIX F

OUTDOOR SCHOOL

Dear

Tprint your name)

Please read each statement and put a mark ( ) above one answer to show how you feel. Mark the atatements qulckly because there are no right or wrong answers. Thank you for your help.
1. I $\frac{\text { care }}{\text { dont care }}$ am undecided whether other people or mygelf take special care of trees and 11d antmalo.

2. I I. care donteare am undeclded whether
other people or myself plck up paper thet other people
throw axound.

3. I cane dont care am indeclded whether other people of myself oollect al1 the fosili from one area.

4. I

$\mathrm{T}$ care dont eare am undectded othe people or myseif remove sand from the beachea to f111 1ow1ands.

5. I

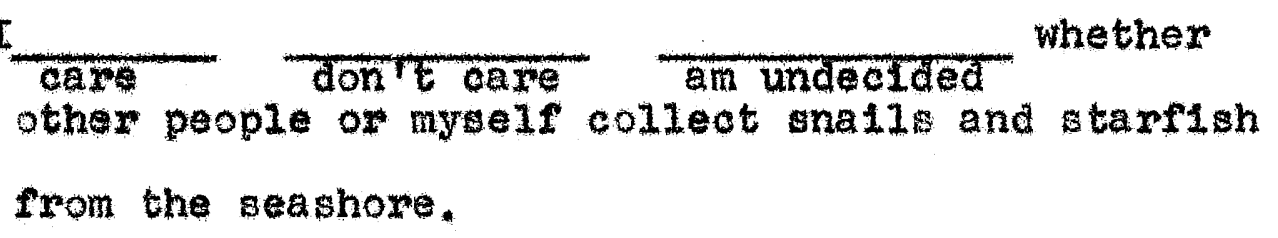


6. I

I care don't care

whether
a spray to k111 all the

other people or myself use a spray to kill all the mosquitoes in one area.

7. I

I.

care dont care am undeclded

whether

other people or myself burn garbage and trash in the out-of-doors.

8. I

care

don't care $\frac{}{\text { am undecided }}$ whether

inftials on rocks.

9. I
I.
care don't care am undeclded whether
other people or myself remove cans and bottles from
rivers, lakes, or from along highways.

10. I care don't care andeclded ${ }^{\text {amether }}$

other people or myself pour waste water into

streams, rivers, or lakes.

11. I

I care
other people or myself cut or paint names on

signs or trees.

12. I

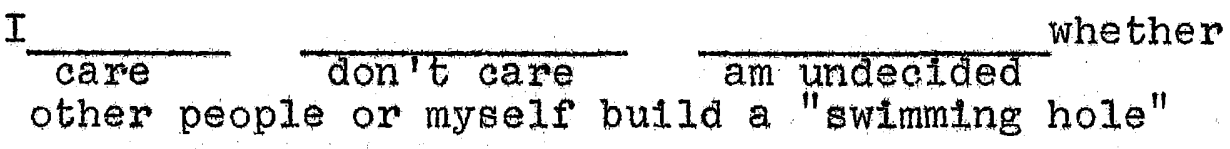

by daming a stream.

13. I

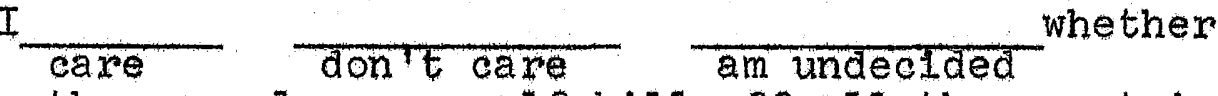

other people or myself k1ll off all the mountain

lions in a park area. 
14. I

I care dontt care am undecided
other people or myself remove old rotten logs from

a park.

15. I

I care dont care am undecided whether other people of myself keep on the trail when walking in the woods.

16. I care dont care am undeclded whether other people or myself plck wild flowers from a forest. 